\title{
Climatic and tectonic controls on sedimentation and erosion during the Pliocene-Quaternary in the Qaidam Basin (China)
}

\author{
Richard V. Heermance ${ }^{1, \dagger}$, Alex Pullen ${ }^{2}$, Paul Kapp ${ }^{3}$, Carmala N. Garzione ${ }^{2}$, Scott Bogue ${ }^{4}$, Lin Ding ${ }^{5}$, and \\ Peiping Song 5 \\ ${ }^{1}$ Department of Geological Sciences, California State University-Northridge, Northridge, California 91330-8266, USA \\ ${ }^{2}$ Department of Earth \& Environmental Sciences, University of Rochester, Rochester, New York 14627, USA \\ ${ }^{3}$ Department of Geosciences, University of Arizona, Tucson, Arizona 85721, USA \\ ${ }^{4}$ Department of Geology, Occidental College, Los Angeles, California 90041, USA \\ ${ }^{5}$ Institute of Tibetan Plateau Research, Chinese Academy of Sciences, Beijing, 100029, China
}

\section{ABSTRACT}

The Qaidam Basin is an internally drained basin located in the northeastern Tibetan Plateau. Presently, over $50 \%$ of the basin floor exposes thick ( $>1 \mathrm{~km})$ sections of PlioceneQuaternary strata that are deformed by folding and faulting. We investigated this nearly continuous Pliocene-Quaternary sedimentary record for the effects of global climate change and deformation on basin sedimentation. New detailed stratigraphic, magnetostratigraphic, and stable isotope $\left(\delta^{18} \mathrm{O}, \delta^{13} \mathrm{C}\right)$ data from the Pliocene Shizigou and Pleistocene Qigequan Formations along the southwestern flank of an intrabasin fold within the north-central Qaidam Basin are presented here. Strata reveal climatically controlled, meter-scale parasequences within shallow-lacustrine, marginal-lacustrine, and deltaic lithofacies. Paleocurrents shift from eastward at the base to southwestward for the majority of the section, but they abruptly shift toward the south-southeast in the upper $400 \mathrm{~m}$. Twenty-two magnetozones constrain deposition between 5.2 Ma and ca. $0.8 \mathrm{Ma}$ and reveal that sedimentation rates were fairly constant $(474 \pm 34 \mathrm{~m} / \mathrm{m} . \mathrm{y}$.) from 5.2 to 3.0 Ma, after which time rates abruptly decreased to $154 \pm 40 \mathrm{~mm} / \mathrm{yr}$ before increasing again to $\sim 750 \mathrm{~m} / \mathrm{m}$.y. since $1.2 \mathrm{Ma}$. The $\delta^{18} \mathrm{O}$ values shift from relatively constant values (avg. $-6.8 \%$, range $-9.6 \%$ to $-4.5 \%$ o relative to Vienna Peedee belemnite [VPDB]) to less negative values (avg. $-1.2 \%$, range $-1.2 \%$ o to $-2.7 \%$ VPDB) between 3.1 and 2.6 Ma and to extremely variable values (avg. $-\mathbf{2 . 9 \%}$, range $-8.3 \%$ to $4.0 \%$ o) after ca. 2.6 Ma. The post-2.6 Ma extreme variability in stable isotopes reflects the same timeframe of enhanced climatic cyclicity associated with Northern Hemisphere glaciation. The $\delta^{13} \mathrm{C}$ values remain relatively constant (average $-\mathbf{4 . 0} \%$, range $-5.7 \%$ o to $-1.0 \%$ o) until ca. $0.9 \mathrm{Ma}$, when the values increase to $\mathbf{- 0 . 3 \%}$ (range $\mathbf{- 1 . 0 \%}$ o to $1.5 \%$ ) VPDB. The appearance of growth strata at 3.0 Ma, shallow-water, evaporite deposition after 2.6 Ma, and the observation of paleoyardangs (buried, wind-sculpted landforms) within lake-marginal strata at 2.4 Ma imply that emergence of the adjacent anticline was followed by the shallowing and partitioning of the lake basin and subaerial exposure and erosion of marginal lake sediments. These data reflect a significant change to a more arid climate in the Qaidam Basin between ca. 3.1 Ma and 2.6 Ma, overlapping with the onset of significant Northern Hemisphere glaciations and basin-floor deformation. Lake-level cycles were on $\sim 230,000$ yr frequency from 2.6 Ma to $1.2 \mathrm{Ma}$, before increasing to $\sim 12,000 \mathrm{yr}$ frequency, suggesting increased aridity and broad, subaerial exposure of lake sediments after the PlioceneQuaternary transition. Deformation of intrabasin sediments by at least 3.0 Ma caused uplift of the basin floor, which provided an environment rich in friable material for wind deflation of the Qaidam Basin, a likely source for sediments on the Chinese Loess Plateau and nutrients for the Pacific Ocean carried by westerly winds. By $2.6 \mathrm{Ma}$, deformation of the Qaidam Basin created closed depressions that facilitated evaporite sedimentation that continues today. Coeval intrabasin deformation, combined with increasing aridity after
3.1 Ma, thus controlled both deposition and erosion within the region.

\section{INTRODUCTION}

The tectonic evolution of the 5000-m-high Tibetan Plateau during the Cenozoic Era occurred simultaneously with distinct, global climatic shifts. Both tectonic uplift and climate change can influence sedimentation patterns, and thus any causal interpretation of stratigraphy must account for both tectonic and climatic influences. Strata preserved within the Qaidam and other nearby basins in the northeastern Tibetan Plateau record tectonic and climatic changes since at least Paleocene time (Pares et al., 2003; Fang et al., 2003, 2007; Horton et al., 2004; Zhou et al., 2006; Yin et al., 2008; Craddock et al., 2011; Zhuang et al., 2011b; Lease et al., 2012; H.-P. Zhang et al., 2012). Differentiating the tectonic versus climatic controls on sedimentation at any of these localities, however, is complicated by the competing influences of both tectonics and climate on sedimentation. For example, both accelerated tectonic growth and a climate change to a cooler and more oscillatory climate may result in increased erosion and sedimentation rates adjacent to and within a basin, respectively. Moreover, accelerated uplift of the Tibetan Plateau has been interpreted to contribute to global cooling and/or enhanced aridification in central Asia, making stratigraphic interpretation of climate and tectonics potentially redundant (e.g., Manabe and Holloway, 1975; Manabe and Broccoli, 1990; Raymo and Ruddiman, 1992). The facies changes observed in the basins within and adjacent to the Tibetan Plateau nevertheless provide an invaluable data

E-mail: richard.heermance@csun.edu.

$\overline{\text { GSA Bulletin; }}$

doi: 10.1130/B30748.1; 13 figures; 1 table; Data Repository item 2013102. 
set to interpret climate, tectonics, and potentially the interactions between the two.

There is unequivocal evidence for climate cooling and aridification in central Asia in the late Pliocene and early Quaternary (3.6$2.6 \mathrm{Ma}$ ) based on red-clay and loess-paleosol strata of the Chinese Loess Plateau located near the northeastern margin of the Tibet-Qinghai Plateau (Fig. 1). Loess deposition, related to the change to a cooler climate, initiated as early as ca. $22 \mathrm{Ma}$ (Guo et al., 2002), and loess sedimentation rates increased at $3.6 \mathrm{Ma}$ and $2.6 \mathrm{Ma}$ (Burbank and Li, 1985; Sun et al., 1998; Ding et al., 1999; Guo et al., 2001; Porter, 2001; Hao and Guo, 2004). These data are consistent with the observed increase in dust flux into the northwestern Pacific at 3.6 Ma (Rea et al., 1998) and with global records of marine $\delta^{18} \mathrm{O}$ values for the same time period (i.e., Raymo and Ruddiman,
1992; Lisiecki and Raymo, 2005). The change to a cooler (i.e., glacial or stadial) climate likely caused increased erosion, which resulted in the observed increase in sedimentation rates and grain size within many depocenters in central Asia (Métivier et al., 1999; Zhang et al., 2001). Alternatively, sedimentation rate and grain-size increases could also be caused by rapid uplift along the northern margin of the Tibet-Qinghai Plateau in the absence of precipitation changes (Sun and Liu, 2000; Zheng et al., 2000; Pares et al., 2003; Fang et al., 2007; Liu et al., 2010; Suarez et al., 2011). Orographic blocking by the Tibetan Plateau is widely regarded as the major forcing mechanism for the observed global climate change between 3.6 and 2.6 Ma (Ruddiman and Kutzbach, 1989; Raymo and Ruddiman, 1992; Hsu and Liu, 2003; Li et al., 2011; Kapp et al., 2011), although direct links between tectonic uplift and climate change remain debated (Molnar, 2005). Thus, understanding the transitional time period between the Pliocene warm period and the onset of Northern Hemisphere glacial cycles at ca. $2.8 \mathrm{Ma}$ is critical to evaluating the forces and feedbacks between tectonics and climate in the development of the Tibetan Plateau region.

In an effort to separate the climatic and tectonic controls on sedimentation within the northeastern Tibetan Plateau region, this study focuses on Pliocene-Quaternary fluviolacustrine strata within the north-central Qaidam Basin. Recent uplift and erosion of the basin floor have exposed a continuous, three-dimensional section of sedimentary strata that reveals facies changes related to climate changes and tectonic events since the Pliocene. These strata provide a complete record of facies changes

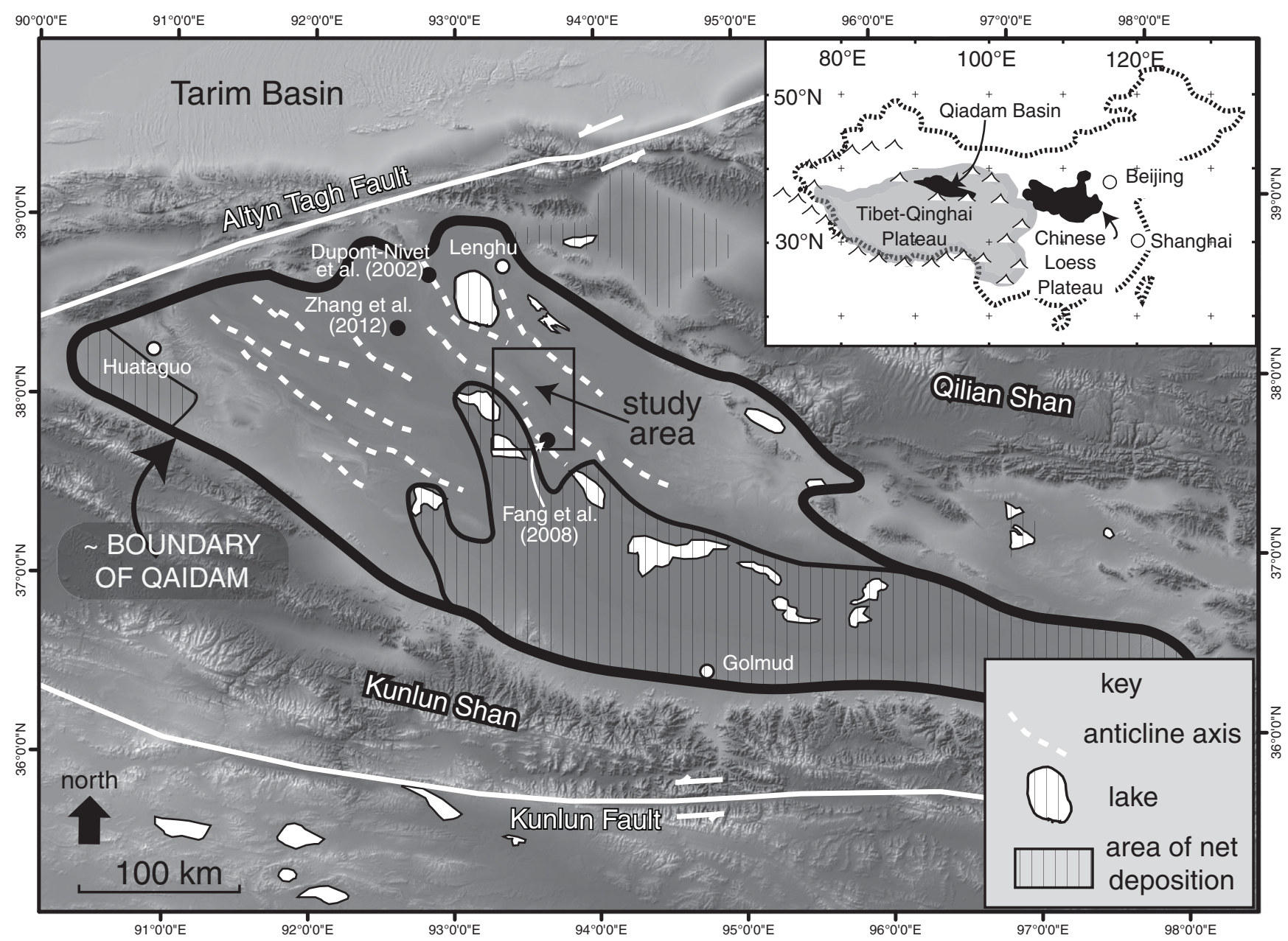

Figure 1. Shaded-relief digital elevation model of the Qaidam Basin. Present-day depozones within the Qaidam Basin are shown as regions with vertical lines. Present-day lake locations are shown, and white dashed lines indicate the axes of intra-basin folds in areas of erosion. Previous magnetostratigraphic study locations are shown as black dots and labeled by their appropriate reference. Inset shows regional setting of Qaidam Basin with respect to the Tibet-Qinghai Plateau (gray region) and the Chinese Loess Plateau. 
and depositional environments that are related to intra- and extrabasin rock uplift as well as the regional climate change between 3.6 and 2.6 Ma. Magnetostratigraphy provides highresolution geochronology for these strata to correlate stratigraphic changes with wellknown global climate events at 3.6 and $2.6 \mathrm{Ma}$, and to interpret the timing of facies boundaries and parasequences, growth-strata ages, and isotopic $(\mathrm{C}$ and $\mathrm{O})$ variability. Parasequences are compared to the well-known loess-paleosol sequences observed on the Chinese Loess Plateau. Paleosols, buried, wind-eroded landscapes, gypsum hardpans, and anomalous wind-controlled lacustrine deposits are used to develop a detailed cyclostratigraphy to test hypotheses about the relationships among aridification, wind-erosion, and tectonic deformation within the Qaidam Basin (Kapp et al., 2011). Integration of facies analysis, magnetostratigraphy, structural interpretation, and geochemical properties of the lacustrine strata provides new, unequivocal insight on the influence of climate change between 3.6 and 2.6 Ma on sedimentation, and also on structural deformation at specific time intervals within the Qaidam Basin since the Pliocene.

\section{GEOLOGIC SETTING}

The Qaidam Basin floor covers $~ 80,000 \mathrm{~km}^{2}$ and is located in the northeastern Tibetan Plateau (Fig. 1). The internally drained basin sits at $\sim 2700 \mathrm{~m}$ in elevation and is flanked by $>5000 \mathrm{~m}$ peaks of the Kunlun Shan to the south, the Qilian Shan to the northeast, and the Altyn Shan to the northwest. Average precipitation is less than $50 \mathrm{~mm} / \mathrm{yr}$. Active deposition occurs in saline lakes, playas, and on basin-marginal alluvial fans (Chen and Bowler, 1986; Mischke et al., 2009), although, at present, over half of the basin floor is actively eroding, as evidenced by the exposed bedrock and yardang fields that cover the northwestern part of the basin (Fig. 1; Halimov and Fezer, 1989; Goudie, 2007; Rubin and Hesp, 2009; Kapp et al., 2011). Since at least the Eocene, however, most of the Qaidam Basin has continuously accumulated sediments, and late Paleozoic and Mesozoic sediments were locally deposited prior to the Cenozoic (e.g., Wang and Coward, 1990; Xia et al., 2001; Rieser et al., 2005; Zhuang et al., 2011b). Cenozoic strata are locally $>5000 \mathrm{~m}$ thick and span from the early Eocene to present (Table S1 in GSA Data Repository ${ }^{1}$ ). Hyperarid conditions combined with internal drainage within the basin have resulted in evaporite and playa deposi- tion throughout the Quaternary and today (e.g., Zhang et al., 2012b).

The Cenozoic tectonic history of the Qaidam Basin is complicated and controversial (Song and Wang, 1993; Chen et al., 1999; Zhou et al., 2006; Yin et al., 2008; Zhuang et al., 2011b). In general, uplift of the basin margins during the Cenozoic produced a regional intermontane synclinorium that accumulated mainly fluvial and lacustrine sediment (Zhou et al., 2006; Yin et al., 2008; Craddock et al., 2011; Zhuang et al., 2011b). A regional unconformity below Paleocene-Eocene strata implies that Cenozoic deposition initiated at 65-49 Ma due to uplift along the northern side of the basin (Yin et al., 2008; Zhuang et al., 2011b). Uplift of the Qilian Shan and Kunlun ranges occurred during the Paleocene and late Oligocene, respectively (Yin et al., 2008). The Qaidam Basin was closed to external drainage in the early Miocene due to displacement along the Altyn Tagh fault and growth of the Altyn Shan, which separates it from the Tarim Basin (Zhuang et al., 2011b). Throughout the Cenozoic, the basin depocenters have shifted southeastward due to partitioning and uplift of the western basin, as deformation propagated toward the southeast (Fig. 1; Chen and Bowler, 1986; Yin et al., 2008). Most recently, uplift of the basin floor due to intrabasin deformation during the Quaternary has exposed late Neogene bedrock in the northern and western part of the Qaidam Basin.

\section{METHODS}

This study measured, described, and sampled an 1750-m-thick stratigraphic section along the southwestern flank of an intrabasin, northeastvergent anticline $\sim 45 \mathrm{~km}$ south of Lenghu town (Fig. 1). Two overlapping sections (NE and MT) spanned a horizontal distance of $\sim 13 \mathrm{~km}$ along the northeast-southwest-trending transect. The Northeast (NE) section is named after its location in the "northeast" part of our field area, and the MaoTai (MT) section is located $\sim 5 \mathrm{~km}$ west along strike of the upper NE section (Figs. 2 and 3). Both sections were measured with a Jacob staff and Abney level. Based on bedding measurements, we estimate that $\sim 300 \mathrm{~m}$ of younger Quaternary strata may overlie this section, until the top of the section where deposition is occurring today.

Samples were collected from 100 sites (sedimentary layers) spaced throughout the lower $1672 \mathrm{~m}$ of the NE section (Table S2 [see footnote 1]), and average sample spacing was $17 \mathrm{~m}$ throughout the section. This spacing was cho- sen to provide on average three sample sites per paleomagnetic reversal since the start of the Pliocene, based on previous estimates of sedimentation rates $(200-900 \mathrm{~m} / \mathrm{m}$.y.; Liu et al., 1998; Fang et al., 2008; Zhang et al., 2012a) and the average duration of a polarity chron (0.25 m.y.) since the start of the Pliocene (calculated from Lourens et al., 2004). Samples were collected as block samples $\left(\sim 5 \mathrm{~cm}^{3}\right)$ extracted from siltstone and fine-sandstone beds with a hammer and chisel, and oriented with a Brunton compass in the field. Samples were cut into $1 \times 1 \times 0.5 \mathrm{~cm}$ chips for paleomagnetic analysis, with the field orientations maintained in the laboratory. The remaining sample was shipped to the University of Rochester for oxygen and carbon isotope analysis.

Paleomagnetic samples were analyzed for both alternating field (AF) and thermal demagnetization in the paleomagnetic laboratory at Occidental College. One sample per site or stratigraphic level was initially measured for natural remanent magnetization (NRM), then subjected to AF demagnetization in four steps up to $20 \mathrm{mT}$ to remove low-coercivity magnetizations, and subsequently treated with stepwise thermal demagnetization using 6-12 demagnetization steps between $200{ }^{\circ} \mathrm{C}$ and $680{ }^{\circ} \mathrm{C}$, typically in $50{ }^{\circ} \mathrm{C}$ steps up to $500{ }^{\circ} \mathrm{C}$ and $30^{\circ} \mathrm{C}$ steps from $500{ }^{\circ} \mathrm{C}$ to $680^{\circ} \mathrm{C}$. At each site, a second and third specimen from the block sample was demagnetized if the first yielded unstable or overprinted directions or if a magnetostratigraphic interval of normal or reverse polarity was defined by only one specimen. Characteristic magnetic remanence (ChRM) directions were determined by line-fit analysis (Kirschvink, 1980) using the paleomagnetic software of Jones (2002). Details on the paleomagnetic sample processing can be found in the GSA Data Repository (see footnote 1).

Oxygen and carbon stable isotopes were measured from carbonate within paleosols, lacustrine strata, and sandstone cement. In total, 57 samples were analyzed from the paleomagnetic sites that had sufficient sample material for both paleomagnetic and isotope analyses. The isotopic results for carbon and oxygen reported here are in the standard delta $(\delta)$ notation with respect to the Vienna Peedee belemnite standard (VPDB). Isotopic ratios were determined at the University of Rochester with a Thermo Delta ${ }^{\text {Plus }}$ $\mathrm{XL}$ continuous flow-isotope ratio mass spectrometer (CF-IRMS) using a GasBench II peripheral device and standard analytical methods (e.g., Hough et al., 2011). Precision for individual analyses was $\pm 0.1 \%$ o for $\delta^{18} \mathrm{O}$ and $\pm 0.06 \%$ o

${ }^{1}$ GSA Data Repository item 2013102, description of methods for sampling and processing the paleomagnetic samples and Tables S1-S4, is available at http://www .geosociety.org/pubs/ft2013.htm or by request to editing@ geosociety.org. 


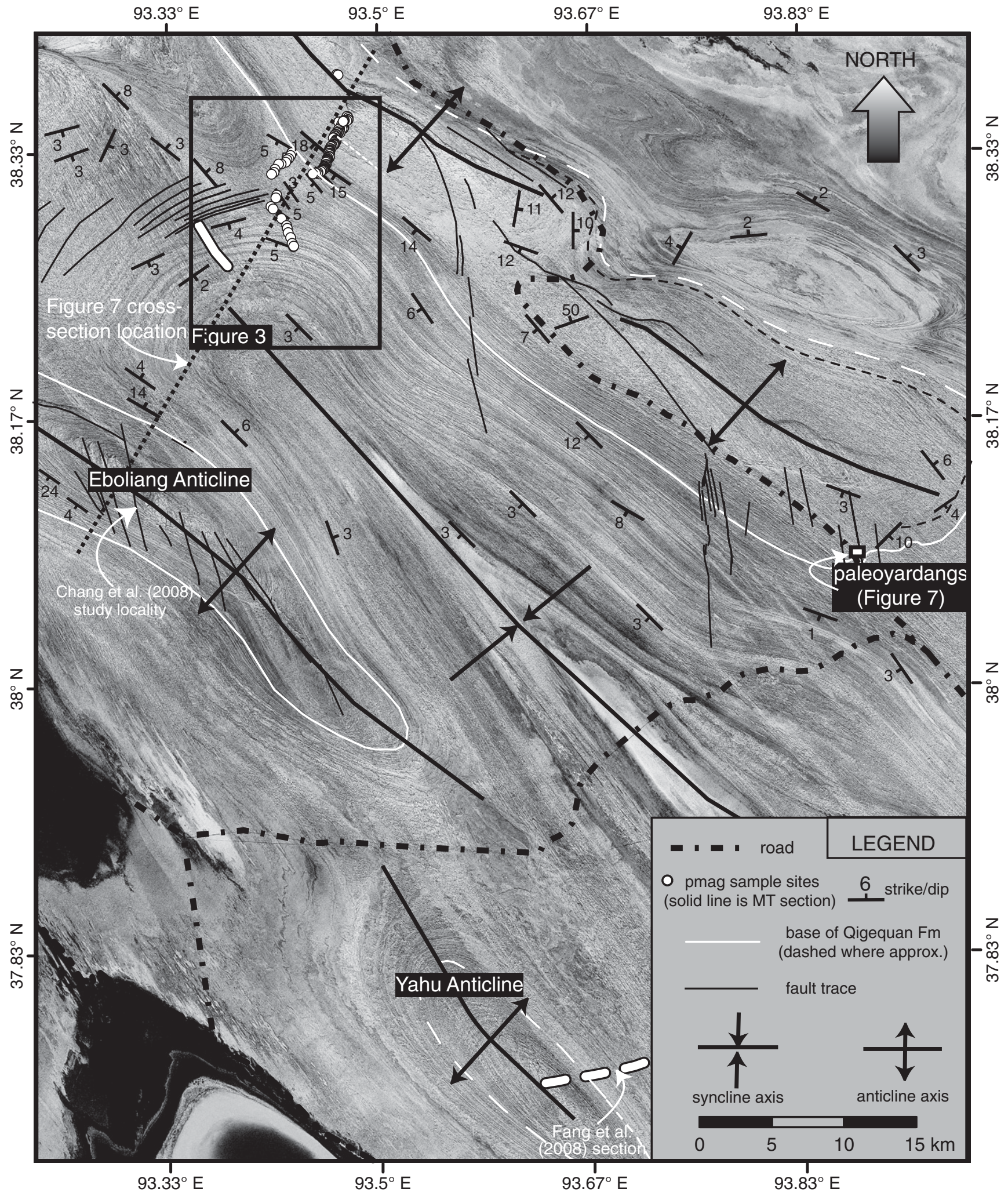

Figure 2. Landsat image of the north-central Qaidam Basin showing the relationship of the study area with the paleoyardang site, folds, and previous work of Chang et al. (2008) and Fang et al. (2008). The base of the Qigequan Formation is from Wang et al. (2012) and this study. Contacts are dashed where inferred or interpreted based on satellite images. Fault traces were interpreted on satellite imagery, and strike-dip data were collected in the field. The cross-section location for Figure 7 is indicated as the dotted line in the upper left. 
Geological Society of America Bulletin, published online on 22 February 2013 as doi:10.1130/B30748.1

Climatic and tectonic controls on sedimentation and erosion, Qaidam Basin

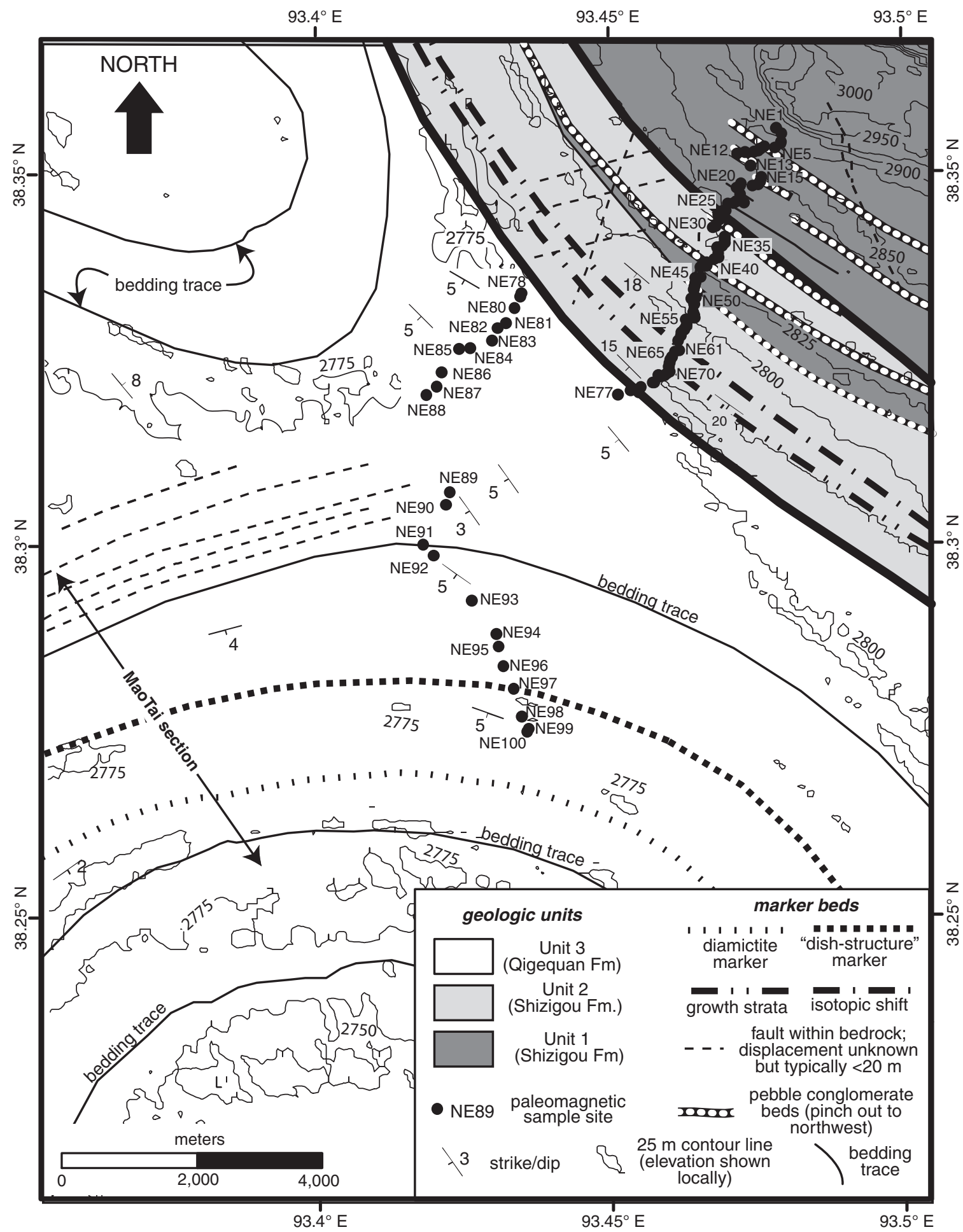

Figure 3. Geologic map of the study area. Paleomagnetic sites for the NE section are labeled sporadically. The MaoTai (MT) measured section location is shown in the lower-left corner of the study area. Notice how unit 1 interfingers with unit 2 and pinches out toward the northeast. Map units are differentiated based on facies associations described in the text. 
for $\delta^{13} \mathrm{C}(1 \sigma)$, whereas sample reproducibility was typically $\pm 0.3 \%$ o for $\delta^{18} \mathrm{O}$ and $\pm 0.17 \%$ o $\delta^{13} \mathrm{C}$ $(1 \sigma)$ when $n \geq 4$. In order to mitigate the effects of erroneous $\delta^{18} \mathrm{O}$ and $\delta^{13} \mathrm{C}$ values from postdepositionally altered carbonate (e.g., Morrill and Koch, 2002), we examined each sample in the field and under a stereoscopic microscope to identify signs of alteration. In the field, samples with signs of surface weathering, or visible gypsum and calcite veins were avoided. Calcite veins identified at the microscopic scale were microsampled using a $20 \mu \mathrm{m}$ drill bit to compare with unaltered micrite in the same sample to determine the nature of diagenesis. In addition, thin sections of randomly selected samples and 10 samples with outlying $\delta^{18} \mathrm{O}$ and $\delta^{13} \mathrm{C}$ values were evaluated to more accurately determine the mineral phases and nature of diagenetic alternation. Lacking evidence of significant postdepositional alteration, no samples were excluded from our data set (see GSA Data Repository [footnote 1]).

\section{SEDIMENTOLOGY}

Late Cenozoic strata within the Qaidam Basin consist of the Upper Youshashan, Shizigou, and Qigequan Formations (Table S1 [see footnote 1]). Microfossils, isotope stratigraphy, and magnetostratigraphy have been used to differentiate between these formations (e.g., Fang et al., 2008; Chang et al., 2008; Pang et al., 2004; Wang et al., 2007; Rieser et al., 2005, 2009). To date, there are few studies of lithofacies or lateral correlation of these strata, making field identification and/or interpretation of sedimentary environments problematic (Wang et al., 2007). This new work presents detailed descriptions of lithofacies and their associations. Strata are divided into three map units based on lithofacies associations and depositional environment (i.e., fluvial, lacustrine, playa, deltaic; Table 1). This rigorous analysis permits interpretation of parasequences and changes in depositional environments over time. Although the focus of this paper is on the chronology of lithofacies variation within one described stratigraphic section, the observed lithofacies are incorporated into the regional formation nomenclature in the discussion section and provide insight into the controls on basinwide facies changes.

\section{Unit 1: Fluvial/Overbank/Mud Flat (0 m-495 m, 760 m-925 m)}

\section{Observations}

The lower $495 \mathrm{~m}$, and a $165 \mathrm{~m}$ interval from 760 to $925 \mathrm{~m}$ of the NE section consist of interbedded shale (M1, M2, M3), sandstone (S1 and S2), and conglomerate (G1). Light-brown

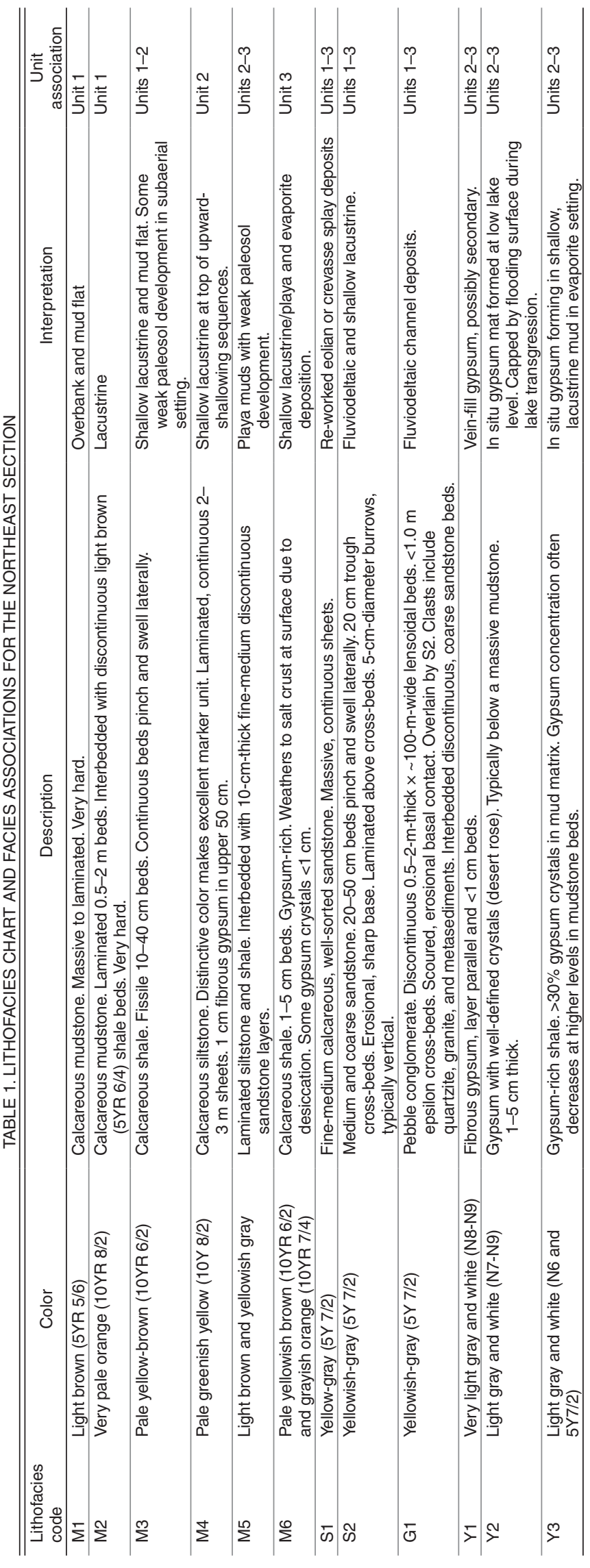


Climatic and tectonic controls on sedimentation and erosion, Qaidam Basin

(5YR 5/6) calcareous mudstone dominates the lowest $100 \mathrm{~m}$ and is interbedded at $\sim 3 \mathrm{~m}$ intervals with 10-40-cm-thick, laminated, continuous fine-grained sandstone sheets (S1). At $\sim 180 \mathrm{~m}$ in the section, calcareous pale yellowbrown shale (M3) appears in the section in sheets that pinch and swell. S1 contains charcoal fragments and weathers with distinctive vertical pipes and gypsum nodules. Discontinuous, 0.5-3.0-m-thick, cross-bedded sandstone lenses (S2) appear at $\sim 10-20 \mathrm{~m}$ spacing (Fig. 4A). Large, (>1.5 m amplitude) epsilon $\left(<15^{\circ}\right.$ dipping) cross-beds are common within these sand lenses. Gravel beds, 0.5-2.0 m thick (G1), occur at $\sim 150,200,250,260,300$, and $400 \mathrm{~m}$ and contain trough ( $<40 \mathrm{~cm}$ amplitude) cross-beds (Fig. 4B). Conglomerate and sandstone lenses pinch out laterally toward the northwest (Fig. 3). Unit 1 is differentiated from the overlying unit 2 by the occurrence of yellowgreen, laminated shale beds. Unit 1 transitions into unit 2 at $495 \mathrm{~m}$ based on the appearance of the first in situ gypsum mat (Y3), but it reappears in the section from $760 \mathrm{~m}$ to $925 \mathrm{~m}$.

\section{Interpretations}

The lithofacies observed between 0 and $495 \mathrm{~m}$ and 760-925 $\mathrm{m}$ are interpreted as ephemeral stream and floodplain deposits (e.g., Hardie et al., 1978). Laminate and massive mudstone and shale represent the floodplain deposits, and discontinuous sandstone and conglomerate lenses represent stream channels meandering through the mud-flat-playa setting (McCarthy et al., 1997; Bridge, 2003). This interpretation is supported by 1.5 -m-tall epsilon cross-beds within the large sand lenses (Fig. 4A). Continuous, laminated sand sheets may represent crevassesplay deposits or reworked eolian sediments blown onto the low-gradient floodplain from nearby abandoned channels (Glennie, 1970; Hardie et al., 1978). Trough cross-bedding within the discontinuous conglomerate sheets is interpreted to represent channel bars within the fluvial system.

\section{Unit 2: Marginal Lacustrine (495 m-760 m,} 925 m-1145 m)

\section{Observations}

The stratigraphy between 495 and $1145 \mathrm{~m}$, not including the interval from 760 to $925 \mathrm{~m}$, is characterized by shale with interbedded sandstone, conglomerate, and gypsum beds (Fig. 5). The base of this map unit is defined by the first appearance of a 1-2-m-thick, pale greenishyellow shale bed (M4). Greenish yellow shale beds are continuous, tabular, and interbedded with light brown and yellowish gray siltstone, sandstone (M3 and M5), and occasionally $<1$-m-thick sandstone (S2) or conglomerate (G1) beds (Fig. 4C).

Unit 2 is easily distinguished from unit 1 by the periodic presence of M4 shale beds that appear within the strata. The base of the first M4 bed is marked by a 2-cm-thick gypsum bed (Y3) composed of $<1 \mathrm{~cm}$ gypsum crystals. A thin $(1-5 \mathrm{~cm})$ shale bed contains ostracods immediately above the gypsum. Between 495 and $760 \mathrm{~m}, 11 \mathrm{M} 4$ beds occur periodically at an average spacing of $24 \mathrm{~m}$, although M4 frequency increases from $\sim 50 \mathrm{~m}$ from 495 to $600 \mathrm{~m}$ to approximately every $15 \mathrm{~m}$ from 650 to $760 \mathrm{~m}$ (Figs. 5A and 5B). M4 beds are absent from 760 to $920 \mathrm{~m}$, but they increase in occurrence from 920 to $1145 \mathrm{~m}$. M4 beds are typically associated with gypsum mats (Y2) at their base or gypsiferous shale at the top of each 1-2 m bed, and they are usually overlain by 0.5 -m-thick sandstone (S2) and underlain by M3 beds (pale-yellow brown calcareous siltstone) interbedded with 20-50 cm trough cross-bedded sandstone beds (Fig. 4C). The top of unit 2 is defined at $1145 \mathrm{~m}$ by the abrupt shift from M4 siltstone strata to M5 shale strata.

\section{Interpretations}

The appearance of tabular, pale greenishyellow beds (M4) marks the beginning of lacustrine deposition in the measured section and may represent times of increased humidity and lake expansion in the basin. The appearance of ooids at the base of the first M4 beds at $495 \mathrm{~m}$ suggests a lacustrine shoreline and supports the interpretation of lake expansion and shoreline transgression. The increasing gypsum content within these beds is the result of lake-shallowing over time, causing an increase in gypsum precipitation and incorporation of well-stratified gypsum/shale layers within the strata (Fig. 4D). M4 layers are typically overlain by fluviodeltaic sediments, which represent a change to fluvial deposition after desiccation of the lake. Fluvial sandstone (S2) and conglomerate (G1) lenses have scoured bases into the underlying M4 or gypsum crust (Y3), and these lenses pinch out into shale and mudstone toward the northeast, consistent with marginal lacustrine or deltaic deposition within a low-relief basin floor (Zaleha, 1997). Overlying the lacustrine strata, there are interbedded shale and sandstone (S2/M3), interpreted as fluvial channel and floodplain deposits (Fig. 4C). The abrupt transition from M3 to M4 within each parasequence implies a rapid increase in lake level and flooding of the floodplain with lacustrine deposits. Overall, we see two trends of increasing lacustrine sedimentation, from 495 to $750 \mathrm{~m}$ and from 920 to $1145 \mathrm{~m}$, interrupted by a period of fluviodeltaic sedimentation from 750 to $920 \mathrm{~m}$. Delta progra- dation can be seen in the distinctive conglomerate beds that pinch out laterally to the northwest within the middle of unit 2 (Fig. 3).

\section{Unit 2-3 Transition Zone (1145-1235 m)}

Between 1145 and $1235 \mathrm{~m}$, lithofacies transition from unit 2, dominated by M3 and M4 strata, to unit 3, dominated by the more gypsiferous M5 and M6 strata. Grain size decreases through this section, from siltstone at the base to shale dominated at the top. Strata above and below this transition zone are self-similar, and thus this narrow zone is broken out into its own section. The transition in lithofacies from unit 2 to 3 will be discussed in a climatic context in the discussion.

\section{Unit 3: Evaporite Lacustrine Facies (1235-1750 m)}

\section{Observations}

Unit 3 constitutes the uppermost part of the Northeast (NE) section as well as the entire MaoTai (MT) section, and it consists of 0.5-2.0-mthick beds of lithofacies M5 and M6 with rare sandstone (S2) beds (Table 1; Fig. 5). The unit is defined by the first appearance of gypsumrich M6 lithofacies at $1235 \mathrm{~m}$, and gypsiferous shale (Y2) and gypsum mats (Y3) increase in occurrence up section (Fig. 5). Gypsum beds increase in frequency from every $30 \mathrm{~m}$ from 1240 to $1440 \mathrm{~m}$, to $8-12 \mathrm{~m}$ frequency above $1440 \mathrm{~m}$ (Fig. 5). In addition to gypsum layers, the section is marked by local disconformities capped by thin lenses of sandstone, and these disconformities increase in frequency toward the top of the section. Outcrops typically are covered in a 10-30-cm-thick gypsum crust, likely derived by dissolution and re-precipitation of salt and gypsum at the outcrop surface. Lithofacies M6 contains ripples, dewatering structures (Fig. 4F), and often grades into gypsiferous shale (Y2) with well-developed, euhedral gypsum crystals ( $<3 \mathrm{~cm}$ diameter) at the top of each bed (Fig. $4 \mathrm{D}$, inset). Occasional conglomerate and sandstone lenses, $\sim 0.5 \mathrm{~m}$ thick and $>100 \mathrm{~m}$ wide, cap many of the gypsum layers within the section.

\section{Interpretations}

Unit 3 represents lacustrine shale and evaporite deposition in a shallow, internally drained lake basin, similar to the sedimentation occurring today within the lake depocenters (Phillips et al., 1993). Gypsum concentration increases in both bed density and within individual beds. Euhedral gypsum crystals up to $3 \mathrm{~cm}$ in length probably formed in situ within the shale within a few centimeters of the sediment-water interface. The repeated sequences of shale with increasing 

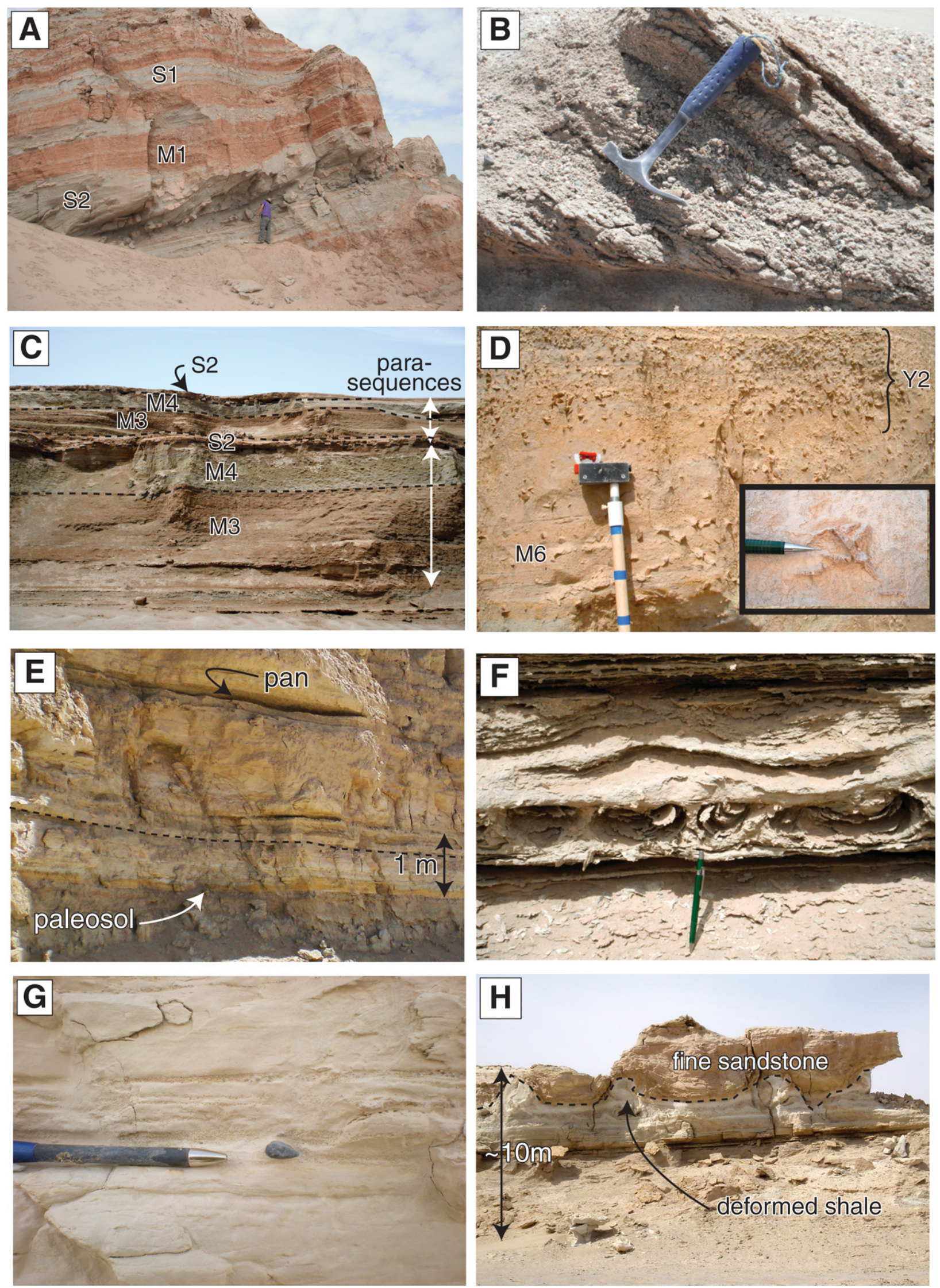
Climatic and tectonic controls on sedimentation and erosion, Qaidam Basin

quantity of gypsum crystals, capped by gypsum beds and overlain by sandstone or conglomerate, are interpreted as the periodic transformation from marginal lake sedimentation to subaerial, playa deposition covered in fluvial deposits (Schubel and Lowenstein, 1997). The increasing gypsum concentration of the Y2 beds is due to lake shallowing, which concentrated the evaporitic minerals in the lake water and facilitated precipitation and growth of gypsum. The increasing frequency of gypsum layers or local disconformities, interpreted as subaerial paleosols, implies periodic lake-level changes and/or desiccation (Schrieber and El Tabakh, 2000). Shale and siltstone deposition in this lacustrine setting was probably controlled by eolian contribution from the lake margins, and will be discussed later herein. The decrease in fluvial sandstone in our section, however, may reflect lateral facies changes, as sampling was focused west of the shoreline and toward the basin depocenter, where fluvial processes were absent.

Figure 4. Photographs of the NE section strata. (A) Lower part of the NE section, showing S2 discontinuous sandstone with $1.5 \mathrm{~m}$ epsilon cross-strata indicating pointbar migration from right to left across the M1 floodplain shale deposits. S1 tabular sandstone sheets are interpreted as reworked eolian strata or crevasse-splay beds. (B) Side view of trough cross-beds within the G1 conglomerate. (C) Parasequences within unit 2 that show the M3 mud-flat shale, M4 lacustrine shale, and S2 irregular fluvial sandstone. Vertical field of view is $\sim 20 \mathrm{~m}$. (D) M6 gypsiferous shale within unit 3 near the top of the section. The upper part of the photo grades into a Y2 gypsum layer. Gypsum layers are defined as any strata with $>25 \%$ gypsum. (E) Fivemeter-high outcrop showing the distinctive paleosol and eolian pan surfaces formed in the M5/M6 lacustrine and mud-flat strata. (F) Intensely deformed M6 strata. Structures are interpreted as polygonal deformation from growth of efflorescent salt crust. (G) Pebble within M6 strata at $225 \mathrm{~m}$ in the MT section within map unit 3. Hard, pitted, subrounded shale fragments are interpreted to have blown into the shallow lake during wind storms, resulting in the diamict texture. Thin, coarse sandy layers are present above and below the gravel clast. $(\mathrm{H})$ Meterscale shale pipes that intrude into overlying fine sandstone layers during soft sediment deformation, probably the result of loading or liquefaction.

\section{Paleocurrents}

Paleocurrents were measured throughout the section and are grouped stratigraphically based on lithofacies associations (Table S3 [see footnote 1]). Trough cross-beds were observed in the S2 and G1 lithofacies, and flow directions were determined by either trendplunge observations from the field-determined trough axis, or by measuring both flanks of the trough and determining the intersection line of these planes. Epsilon cross-beds (Fig. 4A) were interpreted based on the large-amplitude $(>1 \mathrm{~m})$, shallow-dip $\left(<15^{\circ}\right)$ cross-beds within fluviodeltaic channel facies (S2), and they represent point-bar progradation of meandering channel systems, and thus the bidirectional paleocurrent is approximately the strike of these cross-beds. When possible, the strike/ dip of channel margins provided bidirectional paleocurrents, and the upper part of the section contained abundant ripple marks that provided low-energy current indicators.

Paleocurrent data showed variable paleocurrent patterns. The lowest part of unit $1(0-175 \mathrm{~m})$ showed primarily unidirectional paleocurrents toward the east. In contrast, the upper part of unit 1 contained a strong southwest paleoflow, consistent with prograding deltaic sedimentation toward the southwest. Unit 2 also showed strong paleocurrents toward the southwest. Paleocurrent shifted to a more southward direction in unit 3, based on bidirectional (epsilon crossbeds and ripples) current indicators.

\section{Unique Sedimentary Structures Associated with Playa Sediments}

The NE section contains widespread and distinctive planar beds that are distinguished by convoluted and deformed sedimentary structures (Fig. 4F) or a distinctive dark red-orange color (Fig. 4E). They are underlain by mottled, red-green calcareous/gypsiferous shale and siltstone that contain root-trace fossils and carbonate nodules and are in some places overlain by 20 -cm-thick eolian sandstone lenses with trough cross-bedding or 1-2-m-thick fine sandstone with ripple laminations. Where not overlain by fluvial or eolian deposits, these beds are overlain by $10 \mathrm{~cm}$ gypsum hardpan surfaces, 10-cm-thick ooid beds, or simply thick $(>1 \mathrm{~m})$ beds of mudstone and shale. These surfaces are interpreted as subaerial surfaces (paleosols or efflorescent salt crusts) or lake-level lowstands. As flood or lake waters receded, calcareous paleosols or gypsum/ halite hardpan surfaces formed on the exposed surface. Halite-rich muds were distorted due to dissolution processes and growth of efflo- rescent salt crusts above the sandy sediment (Smoot and Castens-Seidell, 1994), or possibly due to shaking and liquefaction during earthquakes (Pratt, 1994). Subsequent deposition on these surfaces caused further deformation. Windblown sand was deposited where surface topography created pans (Fig. 4F; Hardie et al., 1978). Overall, these strata are interpreted to represent subaerial and deflationary conditions along the lake margin.

Postdepositional, meter-scale soft-sediment deformation is also observed in the MT section strata (Fig. 4H). Gypsiferous shale is deformed below fine, brown sandstone due to loading of the saturated shale and potentially earthquake shaking, which resulted in the observed, meterscale ball and pillow structures (Pratt, 1994).

At $225 \mathrm{~m}$ within the MT section (correlated to $\sim 1730 \mathrm{~m}$ the NE section in Fig. 5), a 2-mthick fine-sandstone bed with 1-2 cm, angular, lithic fragments occurs above a Y3 gypsum layer (Fig. 4G). Centimeter-scale rock fragments are associated with subcentimeter-thick, discontinuous, coarse sandstone interbeds (Fig. 4G). Large, pitted lithic fragments are not typically observed in lacustrine sediments, and they are a hydrodynamic paradox. One explanation suggests that these coarser clasts are the result of high winds that carried both lithic gravel and loess from the shoreline, as a projectile, into the adjacent lake. This interpretation could explain the thin, well-bedded, laminated nature of the strata, as episodic deposition of larger grain sizes that were blown into the lake and reworked along the bottom due to wave action. Alternative explanations for these fragments include ice-rafting or wood rafting of the larger clasts, regurgitation by stone-swallowing animals, or deposition by mass-flow deposits (Doublet and Garcia, 2004). These latter explanations, however, do not explain the laminated, well-sorted nature of the gravel layers, and thus wind deposition of projectiles is the preferred explanation.

\section{Paleoyardangs}

Approximately $45 \mathrm{~km}$ southeast and along strike of the NE section, we observed ovalshaped angular unconformities within the lower part of the unit 3 strata. These structures comprised oval-shaped buttress unconformities enclosing a map-view area of $\sim 100 \mathrm{~m} \times 50 \mathrm{~m}$ (Fig. $6)$. The strata below the unconformity consist of red and gray lacustrine siltstone and fine sandstone that dip $19^{\circ}$ toward the southeast. Above the buttress unconformity, lacustrine siltstone dips only $6^{\circ}$ southeast. Vertical relief within the unconformity is a minimum of $6 \mathrm{~m}$, based on similar strata that sit above the unconformity 
Geological Society of America Bulletin, published online on 22 February 2013 as doi:10.1130/B30748.1

Heermance et al.

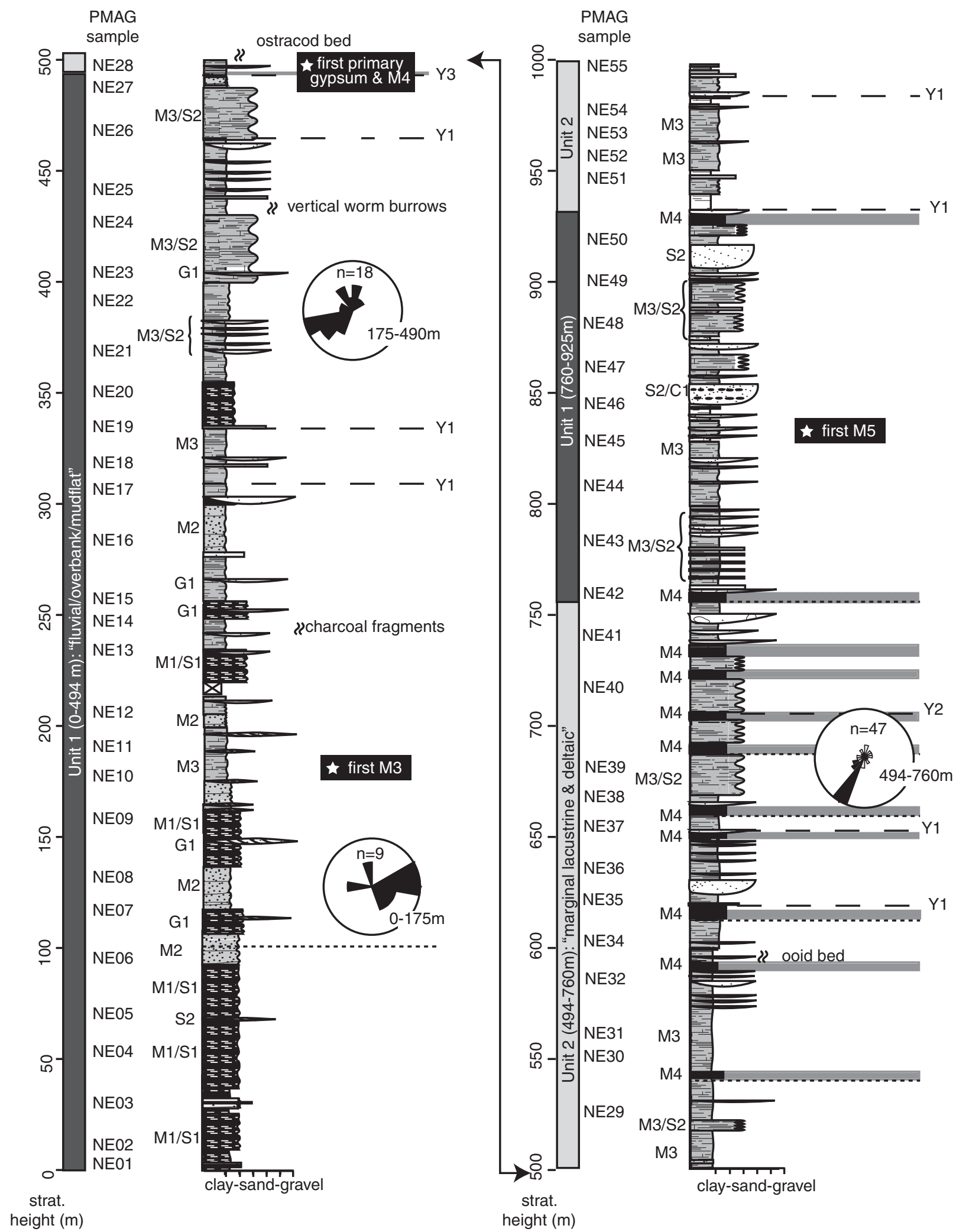

Figure 5 (Continued on facing page). Stratigraphic columns from the NE and MT sections. Sample site stratigraphic positions are shown for all paleomagnetic (PMAG) locations, and samples analyzed for $\mathrm{d}^{18} \mathrm{O}$ and $\mathrm{d}^{13} \mathrm{C}$ are shown in bold. 
Geological Society of America Bulletin, published online on 22 February 2013 as doi:10.1130/B30748.1

Climatic and tectonic controls on sedimentation and erosion, Qaidam Basin

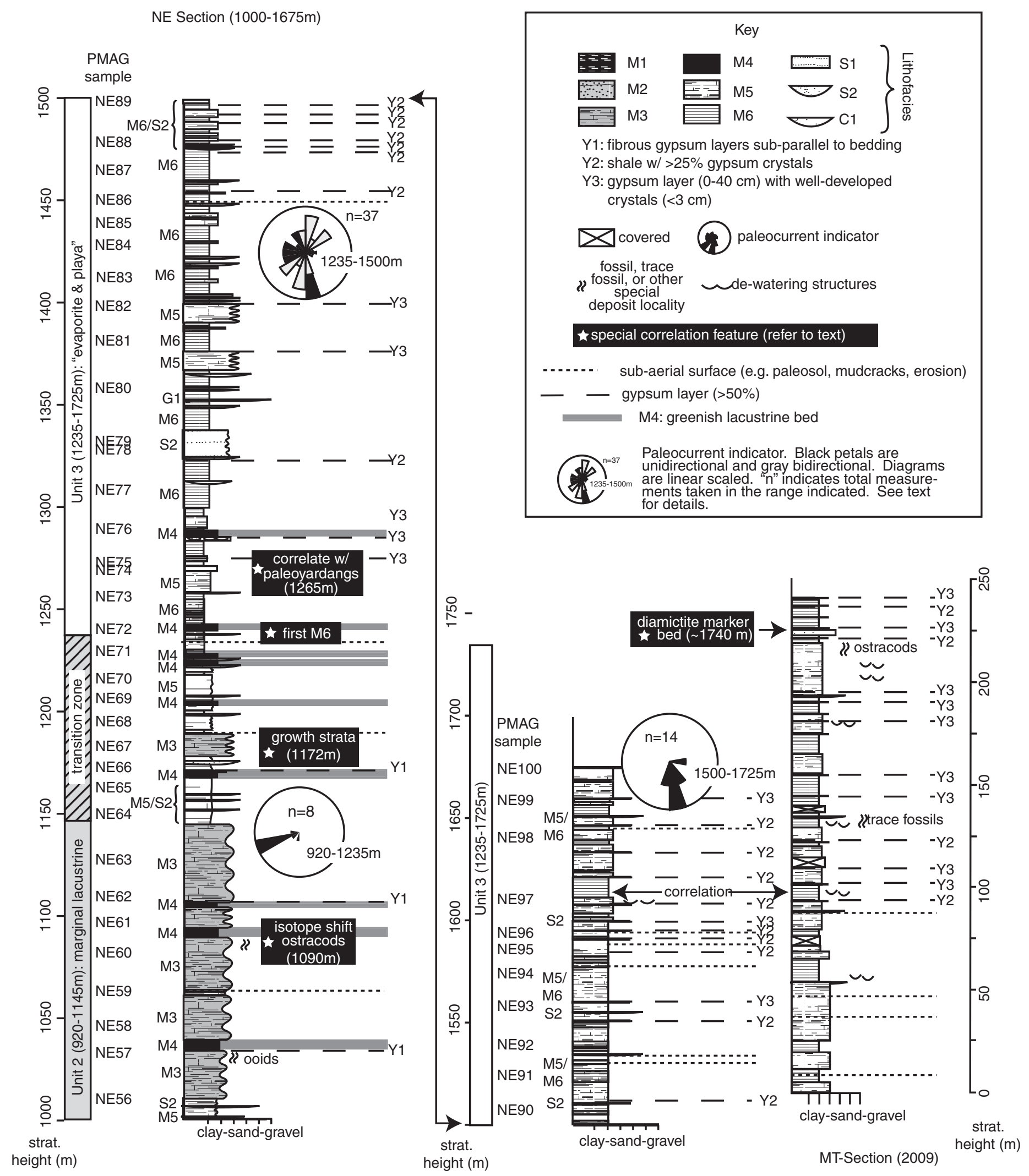

Figure 5 (Continued). 


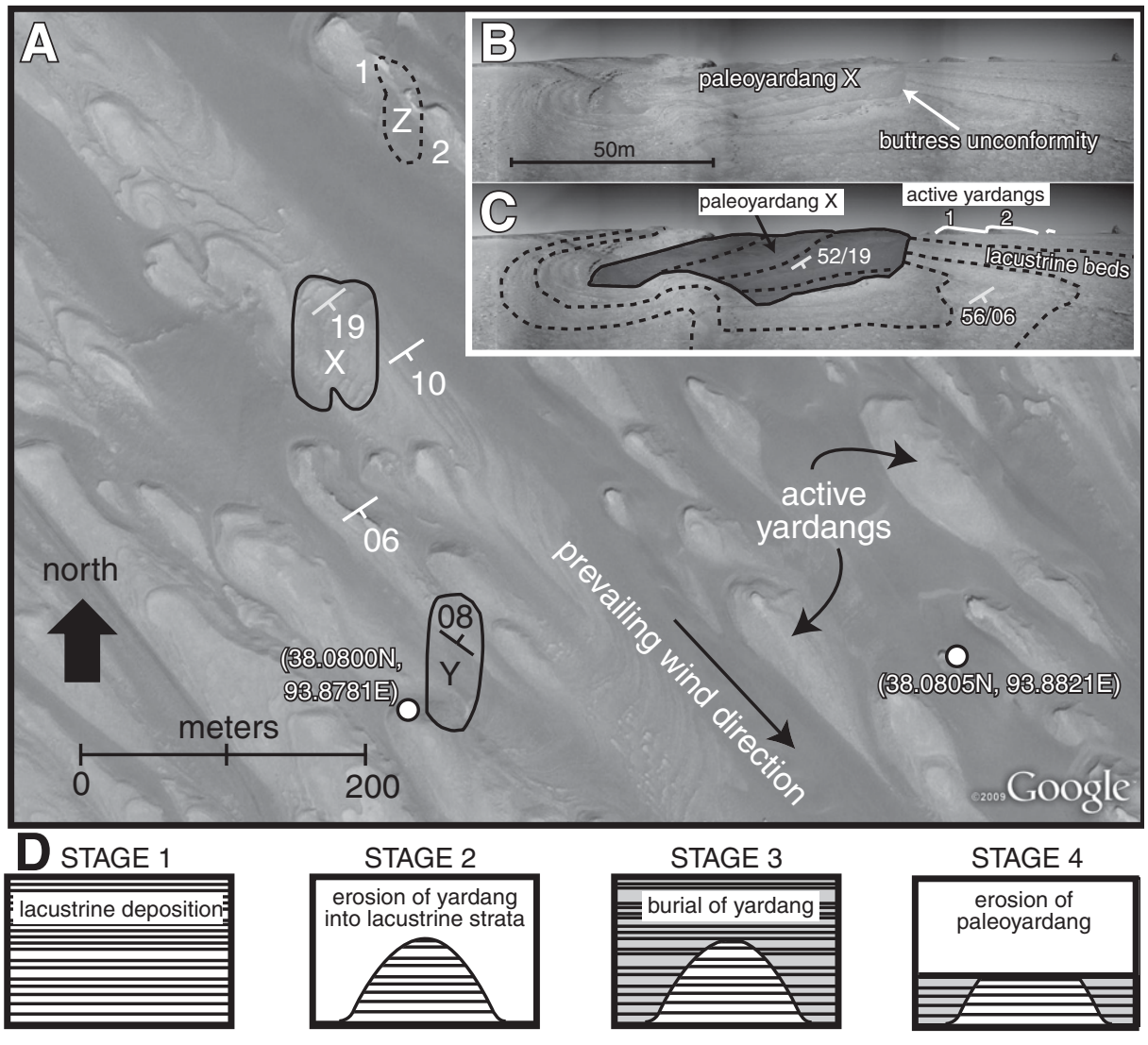

Figure 6. (A) Google Earth image of active yardang field in the northern Qaidam Basin. Outlined areas labeled $\mathrm{X}, \mathrm{Y}$, and $\mathrm{Z}$ are the locations of paleoyardangs observed within the younger lacustrine strata and described in the text, and may represent a paleoyardang field. Strike and dip of bedding are shown in degrees. (B, C) Photograph and geologic interpretation of paleoyardang $\mathrm{X}$, view to north. (D) Schematic model of yardang formation.

exposure. Similar oval unconformities were observed within $1 \mathrm{~km}$ of the structure shown in Figure 6.

The strata bounded below the buttress unconformities are interpreted as paleoyardangswind-sculpted bedrock landforms that are preserved within the stratigraphic record (Tewes and Loope, 1992; Jones and Blakey, 1993). No evidence of fluvial erosion or channel formation was found that might otherwise have produced the unconformities. Yardangs are widespread throughout the Qaidam Basin (Halimov and Fezer, 1989; Goudie, 2007; Rubin and Hesp, 2009), they typically occur in fields, and it follows that they should be preserved (in multiple) in the stratigraphic record. Paleoyardangs formed when bedrock, in this case, cemented lacustrine strata, was exposed due to folding above active structures. Exposed strata were eroded into yardangs due to deflation and abrasion from long-term unidirectional winds. Subsequent rise in lake level caused burial of the yardangs (Fig. 6D). The greater dip of the strata below the unconformity supports our hypothesis that strata were deformed and exposed prior to deposition of the overlying strata. Re-exhumation of the buried yardang resulted in the appearance of oval unconformities within the strata. The paleoyardangs described here are elongated in a N-S direction, implying northerly wind patterns during yardang formation, in contrast to the present northwesterly winds in the Qaidam Basin. The presence of paleoyardangs within the stratigraphic record implies that windy, dry conditions were present prior to deposition of the overlying strata, and they provide a unique paleoclimate indicator for the Qaidam Basin.

\section{Growth Strata}

An angular unconformity and abrupt decrease in dip are observed at $1170 \mathrm{~m}$ (Fig. 7) and are interpreted as growth strata that define the boundary between pre- and syntectonic strata along the back limb of the anticline.
Growth strata are defined as strata deposited adjacent to or above a growing structure, and they can be defined on the basis of fanning dips or rapid changes in thickness across a fold hinge (i.e., Riba, 1976; Suppe et al., 1997). The geometry of growth strata in the NE section shows rapidly decreasing dips, from $20^{\circ}$ to less than $5^{\circ}$ over a short $(\sim 100 \mathrm{~m})$ stratigraphic thickness. A lateral change in bed thickness was not observed, but the short-wavelength rotation (Suppe et al., 1997) of dips suggests that the strata formed due to hinge rotation, possibly above a listric thrust fault at depth (Fig. 7). The observations that strata dip homoclinally $\left(20^{\circ} \pm 5^{\circ} \mathrm{SW}\right)$ from 0 to $1170 \mathrm{~m}$ within the NE section, and then rapidly transition to shallow dips, coinciding with the observed angular unconformity, provide strong evidence for the base of syntectonic strata at $1170 \mathrm{~m}$ (Fig. 7). The location is unlikely to represent that of a simple fold hinge, because the angular unconformity would not be present in that case. Growth of the fold, combined with onlap on the fold flank, is interpreted to have produced the fanning dips from $20^{\circ}$ to $5^{\circ}$ over $<100 \mathrm{~m}$ in stratigraphic thickness. The age of the contact at $1170 \mathrm{~m}$ thus represents a minimum age for the initiation of fold growth, because it is possible that older growth strata could have been eroded at a structurally higher level in the section.

\section{ANALYTICAL RESULTS}

\section{Paleomagnetic Directions}

Progressive demagnetization successfully resolved multiple components of magnetization. For most specimens, equal-area projection and orthogonal vector plots reveal two clear components: a high-temperature component and a low-temperature component (Figs. 8C-8E). The low-temperature component typically had a non-tilt-corrected orientation similar to the present-day magnetic field direction and was removed by $\mathrm{AF}$ demagnetization at $10 \mathrm{mT}$ and thermal demagnetization of $200{ }^{\circ} \mathrm{C}$. On most orthogonal vector plots, the high-temperature component decayed linearly to the origin and was completely removed by heating to $580{ }^{\circ} \mathrm{C}$ or $680{ }^{\circ} \mathrm{C}$, indicating magnetite or hematite as the carrier of the magnetic remanence. The intensity of NRM for these specimens ranged from $10^{-2}$ to $10^{-4} \mathrm{~A} / \mathrm{m}$.

Of the 143 samples processed, 107 yielded clearly defined high-temperature components that we interpret as the characteristic magnetic remanence (ChRM) directions (Table S2 [see footnote 1]; Figs. 8A-8B). Samples without a clear ChRM direction may have resulted from postdepositional resetting, such as late-stage 


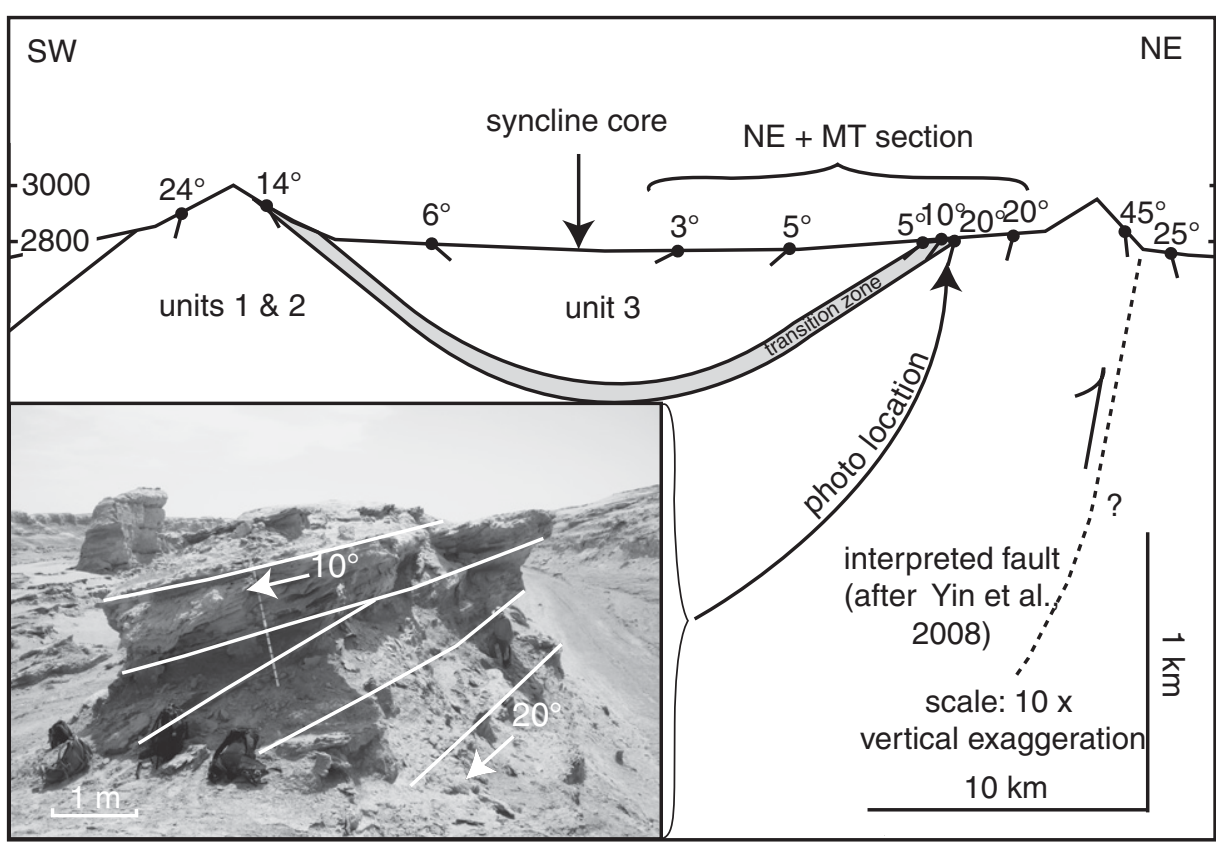

Figure 7. NE-SW cross section through the study area showing the location of growth strata on the southwest limb of the fold. Inset photograph shows the angular unconformity and decreasing dips at the growth-strata outcrop. $1.5 \mathrm{~m}$ Jacob staff is shown near arrowhead adjacent to 10 degree label. Strata change abruptly from $20^{\circ}$ to $10^{\circ}$ at the angular unconformity.

fluid flow, exposure to elevated temperatures, lightning strikes on the outcrop, or other unknown postdepositional processes that destroyed the primary remanence of the sample (e.g., Butler, 1992).

The average, tilt-corrected direction from normal polarity samples is $\mathrm{D}=355.0^{\circ}$ and $\mathrm{I}=42.3^{\circ}$ and from reverse polarity samples is $\mathrm{D}=177.7^{\circ}$ and $\mathrm{I}=-42.2^{\circ}$. These values are consistent with nearby studies of Pliocene-Quaternary strata from the Eboliang anticline (Fig. 1; DupontNivet et al., 2002) that observed mean paleomagnetic directions of $\mathrm{D}=8.0^{\circ}$ and $\mathrm{I}=43.0^{\circ}$, and from the Chahansilatu playa drill site with directions of $\mathrm{I}=52^{\circ}(\mathrm{N})$ and $\mathrm{I}=-41^{\circ}(\mathrm{R})$ (Fig. 1; Zhang et al., 2012a). Inclination values from all these studies are lower than that expected $\left(58.1^{\circ}\right)$ for the Pliocene magnetic field interpreted for Eurasia at that time (Besse and Courtillot, 2002). This inclination shallowing, also common in other sedimentary rocks from the Qaidam and Tarim Basins, has been attributed to depositional processes, sediment compaction, or rock-magnetic effects during deposition (Dupont-Nivet et al., 2002; Tan et al., 2003). Regardless of the cause, the shallow inclination has no effect on our polarity interpretations.

The reversal test (McFadden and McElhinny, 1990) was used to assess whether the mean paleomagnetic directions are free of a common secondary component and so can be taken as accurate measures of the ancient geomagnetic field. The mean tilt-corrected normal and reverse directions are almost exactly antipodal $\left(176.5^{\circ}\right.$ apart) and so "pass" the reversals test. Because of the high dispersion, however, the test is classified as type " $\mathrm{C}$," meaning that only a relatively prominent unremoved secondary component would be detectable via the test. The reversals test is positive (and class "C") whether multiple samples from the same horizon are averaged or each sample is treated as independent data. The dispersions of the paleomagnetic directions in geographic and stratigraphic (i.e., tilt-corrected) coordinates are not significantly different, and so a standard paleomagnetic fold test on the age of the remanence is inconclusive. We observe, however, that the effect of the tilt correction is to move the mean $\mathrm{N}$ and $\mathrm{R}$ inclinations closer (by $\sim 10^{\circ}$ ) to the expected ancient field direction. This evidence, plus the positive reversals test, suggests that we have isolated a primary remanence well enough to produce a robust magnetostratigraphy.

\section{Magnetostratigraphy}

Magnetozones were defined by at least two samples or sites with consistent polarity. Stratigraphic horizons that contained only one sample with a specific polarity, which could not be replicated, are illustrated in Figure 9 as gray zones, but they are not discussed in the results or used in the magnetostratigraphic correlation. Many previous magnetostratigraphic studies employed a methodology that ranks sites based on two or more samples per site (e.g., Johnson et al., 1982; Kempf et al., 1998; Schlunegger et al., 1997; Ojha et al., 2000; Chen et al., 2002). Given that studies of correlative, nearby Qaidam Basin strata found magnetizations to be relatively straightforward in terms of polarity ( $\mathrm{N}$ or R) determination (Fig. 1; Dupont-Nivet et al., 2002; Fang et al., 2008; Zhang et al., 2012a), we chose to trade off using multiple samples per horizon for higher stratigraphic resolution (more horizons). This strategy likely sampled each magnetozone at least twice (three on average), and all single-site reversals were checked for consistency with samples from both the same stratigraphic level and the adjacent sites stratigraphically above and below. In addition, all samples were run through the magnetometer right-side-up and upside-down for each thermal demagnetization step to determine whether or not the sample gives consistent readings, and the high accuracy of the computer-controlled magnetometer and consistency of the sample changer at the Occidental College paleomagnetic laboratory reduce much of the laboratory uncertainty in measurements that plagued early studies. For these reasons, we did not consider it necessary to run multiple samples from each site unless the site was at a reversal boundary or defined its own magnetozone.

In our study, 74 of 100 paleomagnetic sites produced ChRM directions to construct our magnetostratigraphy. These samples define 22 magnetozones (11 normal and 11 reverse) across $1672 \mathrm{~m}$ of stratigraphic section (Table S2 [see footnote 1]), and they have an average sample spacing of $\sim 22 \mathrm{~m}$. The preferred correlation of the NE section magnetostratigraphy with the geomagnetic polarity time scale (GPTS) of Lourens et al. (2004) spans 4.4 m.y. between ca. 5.2 and $0.8 \mathrm{Ma}$ (Fig. 9). This correlation implies that the short $(\sim 10,000 \mathrm{yr})$ Reunion chron from 2.14 to $2.15 \mathrm{Ma}$ on the GPTS was missed in our section, and that zone R2 (represented by a single site) is not correlated to a chron on the GPTS (Fig. 9). This correlation is also consistent with the general stratigraphy of the Qaidam Basin, which suggests a lithofacies change to evaporite strata at precisely 2.6 Ma (Wang et al., 2007), similar to our observed first appearance of evaporiterich lithofacies M6 in unit 3 (Fig. 9), as well as magnetostratigraphy from the nearby Yahu anticline (Fig. 2), which shows a major lithofacies change to saline, evaporite deposits at $2.6 \mathrm{Ma}$ (Fang et al., 2008). Moreover, the NE section grades upward to within $400 \mathrm{~m}$ of active playa 
Geographic Coordinates

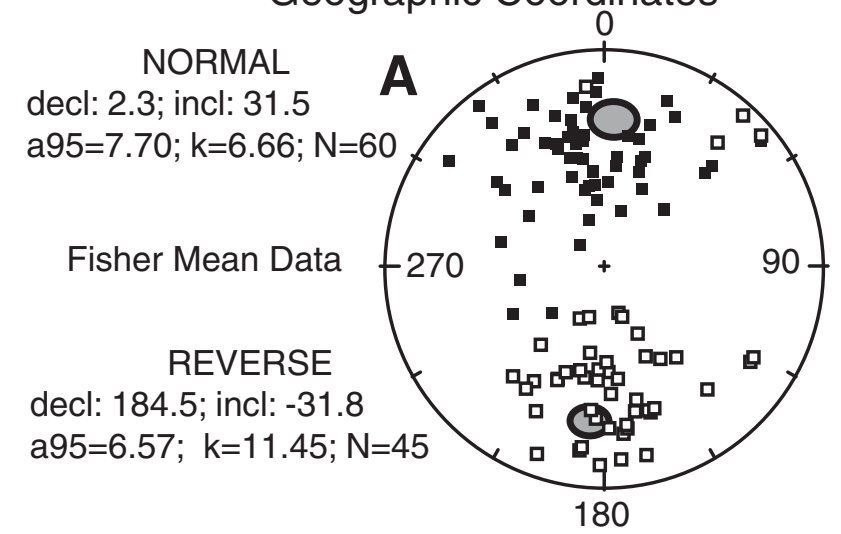

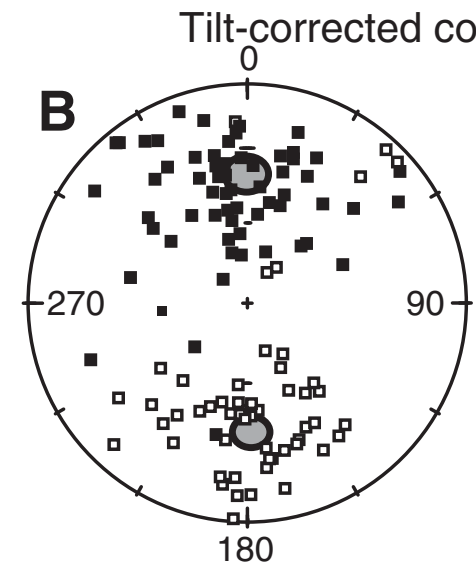

Tilt-corrected coordinates

NORMAL

decl: 355.0; incl: 42.3

a95=7.48; $\mathrm{k}=7.01 ; \mathrm{N}=60$

Fisher Mean Data

REVERSE

decl: 177.7 ; incl: -42.2

a95=6.56; $\mathrm{k}=11.51 ; \mathrm{N}=45$

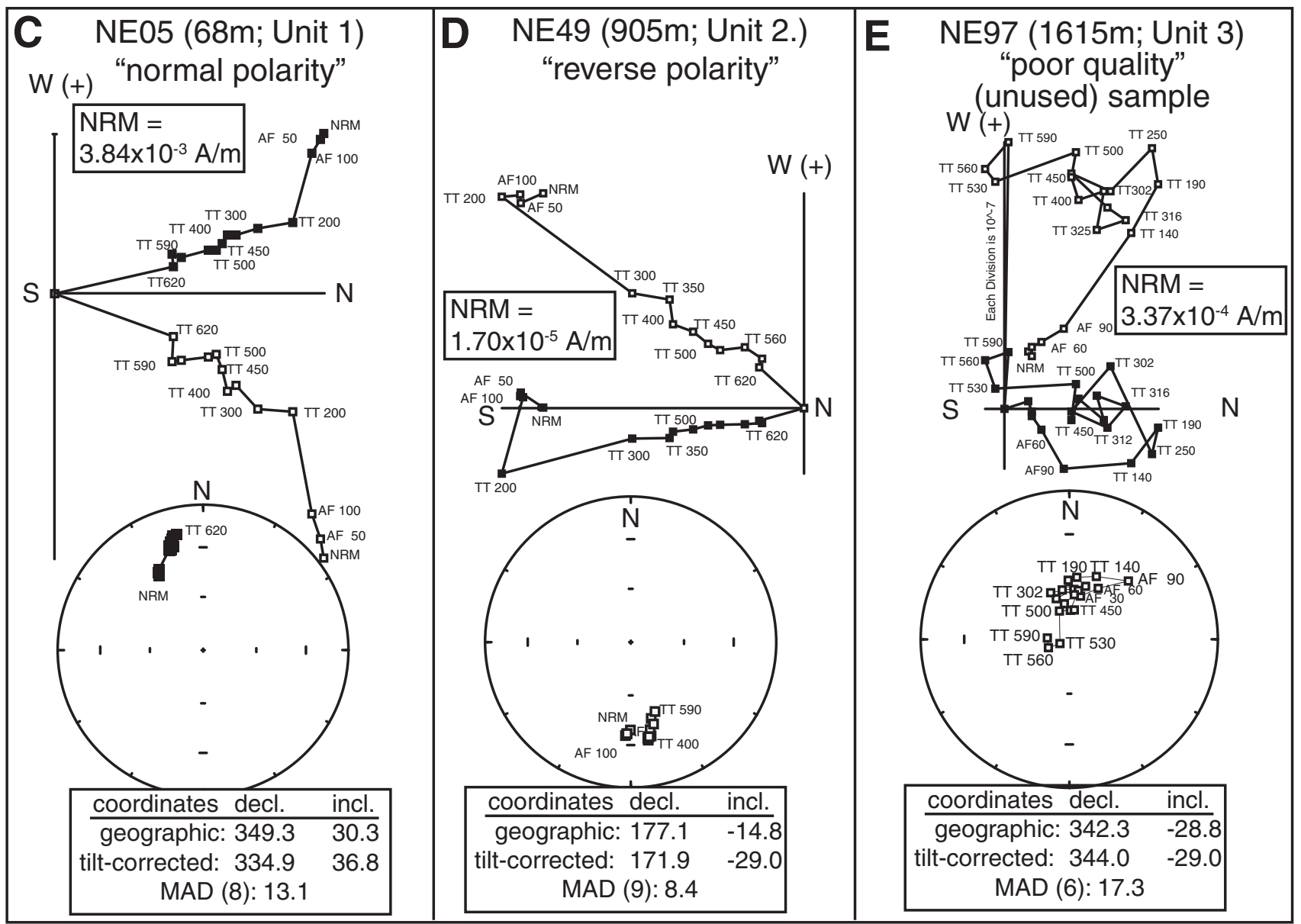

Figure 8. Paleomagnetic data from the NE section. (A, B) Geographic and tilt-corrected coordinates for all samples that yielded clear characteristic remanence directions (ChRM). Fisher mean values for normal (black squares) and reverse (white squares) polarity samples are shown in both geographic and tilt-corrected coordinates. (C-D) Orthogonal vector diagrams and associated equal-area plots of three typical samples that have been progressively demagnetized from their natural remanent magnetization (NRM) shown. Axes are scaled linearly. Data labels indicate level of alternating field ("AF") or thermal ("TT") demagnetization. All plots have been corrected for tectonic tilt. Solid squares show the remanence declination vector projected onto the horizontal plane (with $\mathrm{N}$ to the right); open squares show the inclination vector projected onto the $\mathrm{N}-\mathrm{S}$ vertical plane with the upper half (+) inclined up from horizontal. Two-component remanence data for normal and reverse samples (C, D) from unit 1 are shown. ChRM values are calculated from all data points of $200{ }^{\circ} \mathrm{C}$ and higher. (E) A poor-quality sample that did not provide a clear magnetic remanence direction and was not used in our magnetostratigraphy. MAD—maximum angular deviation. 


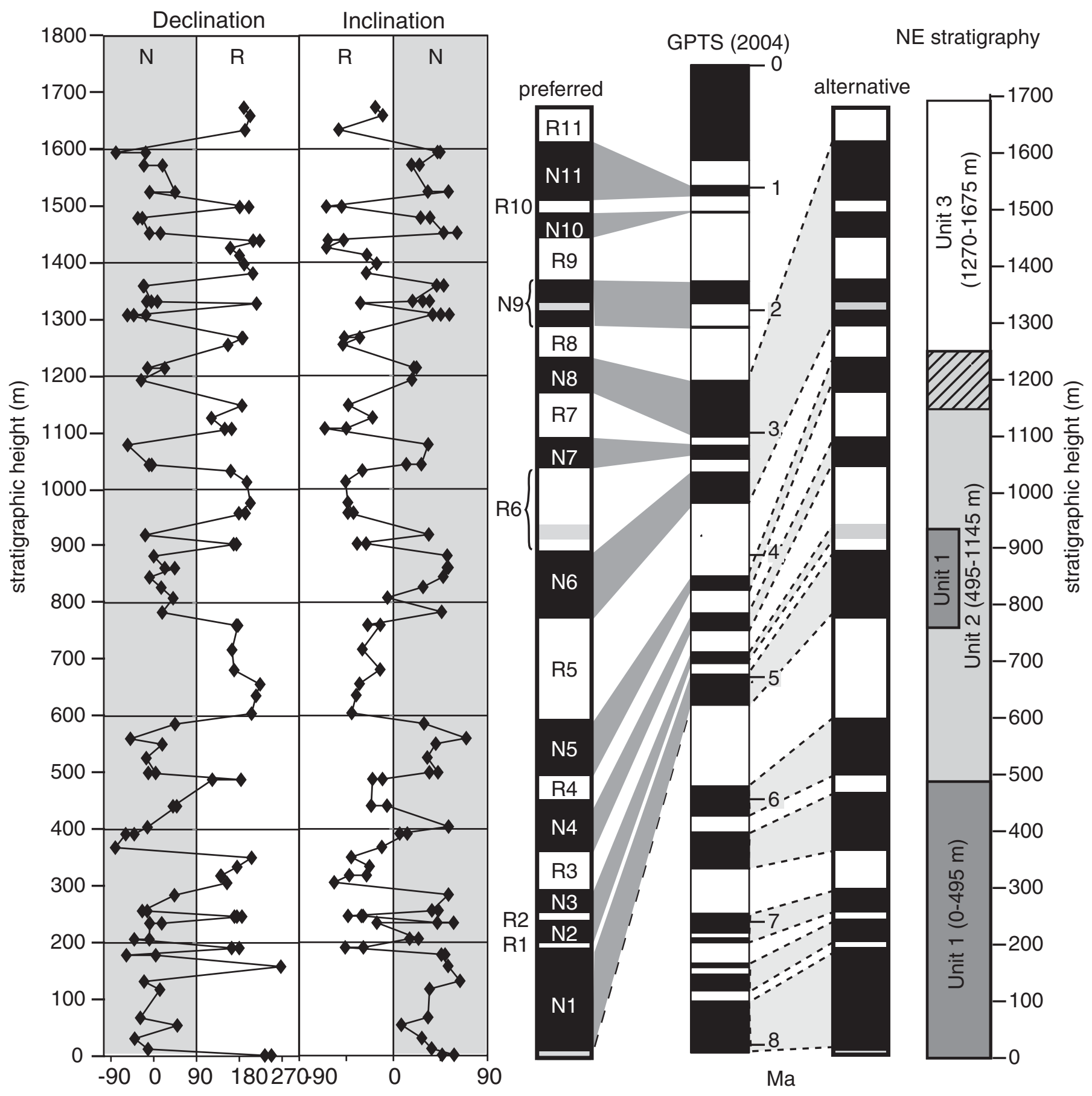

Figure 9. Paleomagnetic data and correlation with the geomagnetic polarity time scale (GPTS) of Lourens et al. (2004). Negative inclination values are up. The preferred correlation is shown on the left of the GPTS, with justifications discussed in the text.

deposition near the core of the syncline southwest of the NE section (Fig. 2), suggesting the upper part of the section should be within the Quaternary, considering sedimentation rates between 0.2 and $0.8 \mathrm{~mm} / \mathrm{yr}$ (Liu et al., 1998; Fang et al., 2008; Zhang et al., 2012a).

For completeness, we include an alternative correlation of the NE section from ca. 2.5 Ma to $8.0 \mathrm{Ma}$ (Fig. 9). This correlation requires that three magnetozones (one normal, two reverse) were missed in our sampling at $4.8(\mathrm{~N}), 7.1(\mathrm{R})$, and 7.4 (R) Ma, respectively. Furthermore, this correlation places the lithofacies transition from unit 2 (fluctuating lacustrine) to unit 3 (evaporite-dominated) ca. 4.0-4.4 Ma, inconsistent with the well-documented change to evaporite-dominated facies at 2.6 Ma. Finally, this correlation implies that the entire section was deposited prior to the Quaternary, inconsistent with previously determined ages for the strata investigated (Fang et al., 2008; Chang et al., 2008; Pang et al., 2004; Wang et al., 2007). Therefore, we reject this correlation based on poor fit and previous work. 


\section{Age of Strata}

Magnetostratigraphic correlation of the NE section with the GPTS places absolute ages on the map units. The base of unit 1 is ca. 5.2 Ma, based on our approximated correlation of the base of N1 with the GPTS reversal at 5.23 Ma. This correlation can only be deemed approximate because of the uncertain reversal (gray magnetozone) at the base of N1 (Fig. 9). This reversal is uncertain because two samples from the lowest site produced clear remanence directions but without a clear normal or reverse polarity (declination $\sim 280^{\circ}$ ). Thus, we cannot be sure that there is a reversal to pin to the GPTS at this location, although placing a reversal there would provide consistent sedimentation rates. The contact between units 1 and 2 occurred at ca. 4.4 Ma, within the R4 magnetozone. Unit 1 reappears from 3.6 to $3.3 \mathrm{Ma}$ in the section, as the deltaic facies prograded northwestward and interfingered with unit 2 . The change from unit 2 (humid-lacustrine) to unit 3 (evaporite/playa lacustrine) occurred between 3.0 and $2.6 \mathrm{Ma}$, and the first appearance of M6, which defines unit 3, occurred at 2.6 Ma (the reversal between R8 and N8). The top of the section is ca. 0.8 Ma. The top cannot be younger than $0.78 \mathrm{Ma}$, because the highest samples show a reverse polarity, and chronozones younger than 0.78 lie within the normal Brunhes chronozone. Overall, the strata analyzed span 4.4 m.y. (5.2-0.8 Ma) with significant stratigraphic changes occurring at 4.4 Ma and 2.6 Ma.

\section{Sediment Accumulation Rates}

Sediment accumulation rates were calculated by plotting the depth of each magnetostratigraphic reversal against its correlated age and fitting a least-squares regression to consistent (linear) sections of data. For completeness, both paleomagnetic correlations are plotted in Figure 9, although for the reasons defined already (i.e., the alternative correlation places all strata older than Quaternary and the base of unit 3 is pinned at ca. 2.6 Ma), we conclude that our preferred correlation is correct (Fig. 9). Errors are two standard deviations from the mean. The accumulation rates are not corrected for postdepositional compaction, because the samples were never deeply buried, and hyperarid conditions suggest that early cementation is likely such that standard porosity-versus-depth curves would be inapplicable. Furthermore, our data imply that sedimentation rates are generally higher for deeper strata, in contrast to that expected due to compaction. Nevertheless, rates presented here are minima, although we consider compaction effects to be insignificant for interpretation of the section.
Units 1 and $2(0-1145 \mathrm{~m})$ display remarkably consistent sedimentation rates of $474 \pm$ 34 m/m.y. (Fig. 10) and are similar to sedimentation rates from the Pliocene determined at other locations within the Qaidam Basin (Liu et al., 1998; Fang et al., 2008; Zhang et al., 2012a). After 3.0 Ma, rates decrease abruptly to $154 \pm$ $40 \mathrm{~m} / \mathrm{m}$.y. This decrease is coincident with the appearance of growth strata and marks the initiation of the lithofacies 2-3 transition. Sedimentation rates remain relatively low until ca. 1.2 Ma in unit 3 (evaporite lithofacies), when rates increase to $730 \pm 325 \mathrm{~m} / \mathrm{m}$.y. The large error associated with this rate is the result of the short duration and low number of reversals for this section. Nevertheless, the data define an abrupt increase in rates after $1.2 \mathrm{Ma}$, very similar to the results from the Chahansilatu playa drill core located $80 \mathrm{~km}$ west of our measured section (Zhang et al., 2012a), where sediment accumulation rates nearly doubled from $261 \mathrm{~m} / \mathrm{m}$.y. to $438 \mathrm{~m} / \mathrm{m}$.y. after 1.0 Ma. The alternative correlation shows remarkably consistent sedimentation rates. No clear change, however, is associated with lithofacies boundaries, as might be expected when changing from a fluvial to lacustrine setting. Moreover, the alternative correlation does not overlap with the ages from the Chahansilatu playa, despite expected stratigraphic correlation between the tops of both sections.

\section{Oxygen and Carbon Isotopes}

Calcareous micrite and calcareous cement samples were collected from units 1-3 (Fig. 11). Samples from 0 to $1145 \mathrm{~m}$ (units $1-2$ ) yielded average $\delta^{18} \mathrm{O}$ values of $-6.8 \%$ o $(n=$ $33, \sigma=1.5 \%$ o and $\delta^{13} \mathrm{C}$ values of $-4.7 \%$ o $(n=$ $33, \sigma=1.1 \%$ ). At $\sim 1100 \mathrm{~m}, \sim 140 \mathrm{~m}$ below the unit 2-3 transition, isotopic values of both $\delta^{18} \mathrm{O}$ and $\delta^{13} \mathrm{C}$ shift toward more positive values and show greater variability. This stratigraphic level equates to 3.1 Ma based on our paleomagnetic correlation. These changes in isotope values are consistent with the depositional facies changes that include wind deflation features (i.e., paleoyardangs), lacustrine wet-dry sequences, and abundant gypsum layers. Samples from unit 3 yielded average $\delta^{18} \mathrm{O}$ values of $-2.5 \%$ o $(n=24$, $\sigma=3.9 \% \circ)$ and $\delta^{13} \mathrm{C}$ values of $-1.5 \%$ o $(n=24$, $\sigma=1.9 \%$ o).

The variability and general trend toward more positive $\delta^{18} \mathrm{O}$ and $\delta^{13} \mathrm{C}$ values are interpreted to record changes in the isotopic composition of

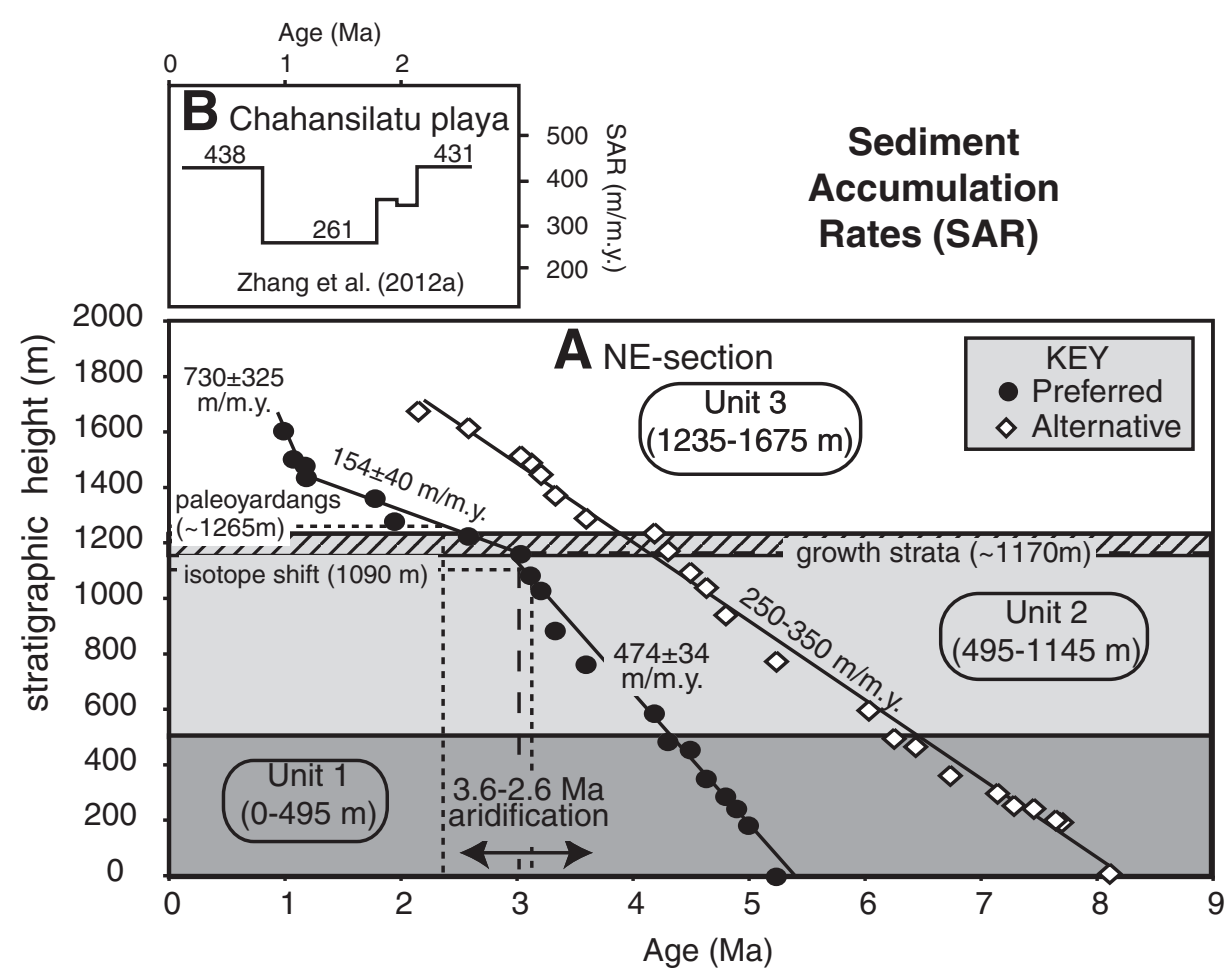

Figure 10. Sediment accumulation rates (SAR) from the NE section (A; this study) and the recently published Chahansilatu playa core (B; Zhang et al., 2012a). NE section rates were calculated by least-squares regression through linear trends, and errors are two standard errors of the slope value. Major events are shown based on the preferred correlation. Unit $1 \mathrm{~b}$ is not shown. 
the meteoric/soil water from which the carbonate precipitated. This interpretation is based on the observations that (1) samples show little sign of diagenetic alteration from interaction with fluids, (2) the increase in variability is near the top of the section, and (3) extreme values do not correlate with any particular lithofacies. We interpret more positive $\delta^{18} \mathrm{O}$ values near the top of the section to represent periods with high evaporation and greater aridity. This interpretation is also consistent with the carbon isotopic record. Plants preferentially uptake ${ }^{12} \mathrm{C}$ during photosynthesis in lakes, resulting in an increase in the $\delta^{13} \mathrm{C}$ values in the surrounding dissolved inorganic carbon (DIC) pool, as well as in carbonate that precipitates from productive waters (McKenzie, 1985; Drummond et al., 1995). Positive $\delta^{13} \mathrm{C}$ values like those recorded near

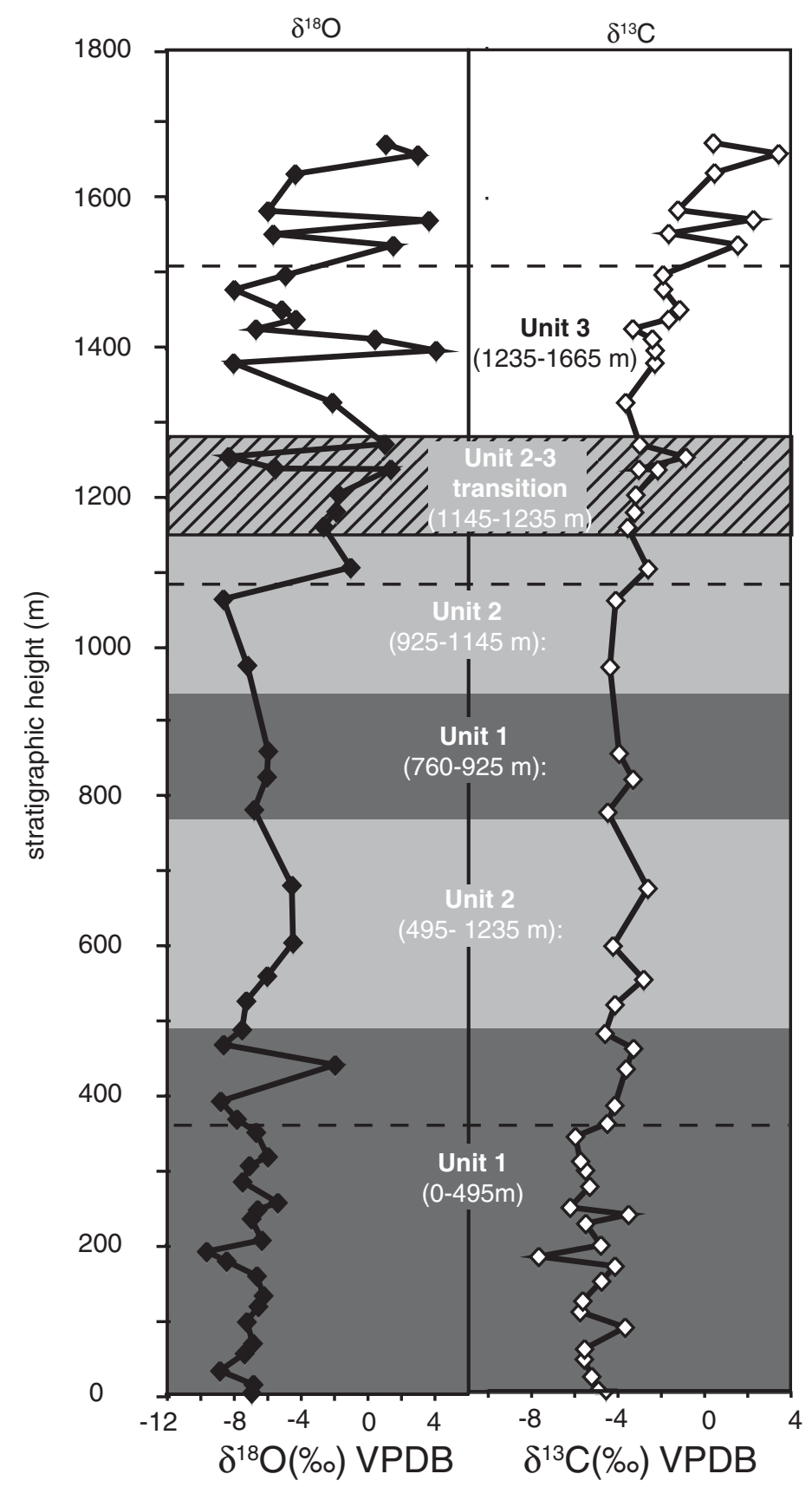

Figure 11. Oxygen and carbon isotope data. Isotopic results are reported in the standard delta $(\delta)$ notation with respect to Vienna Peedee belemnite standard (VPDB). Dashed lines show major changes discussed in the text.

the top of the section in unit 3 are consistent with values observed in highly productive brine lakes (e.g., Katz and Kolodny, 1977; Stiller et al., 1985). Another possible mechanism for increased $\delta^{13} \mathrm{C}$ values in lacustrine carbonates is bacterial methanogenesis during early diagenesis of lake deposits (Talbot and Kelts, 1990). We do not view this as a viable mechanism to explain the trend toward more positive values because the trend to more positive values is gradual, deposits lack the high organic content that would promote bacterial methanogenesis, diagenetic features typically associated with bacterial methanogenesis, such as spar-filled pore spaces, are not observed, and extreme values $(>4 \%$ ) associated with methanogenesis are not observed (e.g., Garzione et al., 2004). These data, coupled with our sedimentological and paleomagnetic investigation, provide an excellent means for reconstructing the paleoclimate conditions for Pliocene-Quaternary time in the Qaidam Basin.

\section{DISCUSSION}

\section{Stratigraphic Nomenclature and Geochronology}

The Pliocene-Quaternary basin fill of the Qaidam Basin provides a rich record of changes in environmental conditions related to deformation and regional/global climate changes. Although many previous studies have focused on the geochemical, magnetic, and paleontological details at individual locations (e.g., Liu et al., 1998; Fang et al., 2007, 2008; Chang et al., 2008; Zhang et al., 2012a, 2012b), very few studies have attempted to integrate data sets to provide a regional perspective (Wang et al., 2007; Zhuang et al., 2011a, 2011b). The result has been an inconsistent chronostratigraphy for the basin, particularly for the Pliocene-Quaternary strata (Table S1 [see footnote 1]). For example, the youngest strata in the basin comprise the Quaternary evaporite-lacustrine Qigequan Formation, interpreted to have formed in response to aridification of the region (e.g., Wang et al., 2007). The proposed age for the base of this formation, however, has varied between 2.6 and $1.8 \mathrm{Ma}$ because this contact has been pinned to the Pliocene-Quaternary boundary, which itself has varied based on lack of general consensus (e.g., Pillans and Naish, 2004). Similar discrepancies are reported for the Pliocene Shizigou Formation, the basal age of which has been assigned a minimum of $5.3 \mathrm{Ma}$ to a maximum $8.2 \mathrm{Ma}$, with very little discussion of potential time-transgressive behavior or facies variability (Table $\mathrm{S} 1$ [see footnote 1]; Y. Wang et al., 2012; X. Wang et al., 2007; Song and Wang, 1993). Overall, age 
discrepancies for these young strata have precluded inferences about tectonic and climatic influences on lithofacies changes within the Qaidam Basin.

This study provides one of the first threedimensional lithofacies evaluations of Pliocene-Quaternary Qaidam Basin strata. Our stratigraphic units can be placed within the regional nomenclature, and they provide new, more-precise ages for the formation boundaries. We place units 1 and $2(0-1145 \mathrm{~m})$ within the Pliocene Shizigou Formation, based on age (5.4-2.6 Ma) and lithofacies (marginal lacustrine and lacustrine deposits; e.g., Chang et al., 2008). We note, however, that the Shizigou Formation in our section includes two distinct lithostratigraphic units (1 and 2) that display an interfingering relationship (Fig. 3), and the upper 100 meters of unit 2 is transitional into the evaporate-rich unit 3 . The transitional zone spans 0.4 m.y., and is included within the Shizigou Formation for this discussion. Thus, field identification of this formation may be complicated by multiple lithofacies. The overall Pliocene age of the Shizigou Formation, however, is consistent with all previous descriptions of these strata (see Table $\mathrm{S} 1$ for references [footnote 1]).

The age of the lower contact of the Shizigou Formation remains undetermined in our study, because we did not recognize a clear formation boundary below the Shizigou strata. The lowest part of the NE section (unit 1) correlates stratigraphically with the Shang Youshashan Formation (14.9-5.3 Ma) within the Eboliang Anticline (Fig. 2; Chang et al., 2008; Wang et al., 2007). If unit 1 is part of the Upper Youshashan Formation, then it must be time transgressive, and get younger toward our section to the northeast, where it is as young as 3.3 Ma. This interpretation, however, is inconsistent with all published ages for the Shizigou Formation that claim the formation is at least $5.2 \mathrm{Ma}$ (Table S1 [see footnote 1]) and with recently published maps that place the entire study area within the Pliocene-Quaternary (fig. 2 in Wang et al., 2012). For simplicity, we prefer to assign unit 1 to the Shizigou Formation based on age relationships, but we recognize that lateral facies changes and time-transgressive strata could result in alternative scenarios, and may imply that the Shang Youshashan Formation is much younger (ca. $3.5 \mathrm{Ma}$ ) than previously determined (>5.2 Ma).

The upper part of the NE section is unequivocally strata of the Qigequan Formation (Chang et al., 2008; Song and Wang, 1993). As noted above, the contact between the Shizigou and Qigequan Formations is transitional and spans $\sim 100 \mathrm{~m}$ between $1145 \mathrm{~m}$ and $1235 \mathrm{~m}$. At $1235 \mathrm{~m}$ (ca. $2.6 \mathrm{Ma}$ ), the first appearance of gypsiferous shale within the strata provides unequivocal evidence for the evaporite-rich Quaternary Qigequan strata at this location, and it is the basis for our formation boundary. This change from lacustrine to evaporite strata is widespread throughout the Qaidam Basin (Song and Wang, 1993; Rieser et al., 2005; Zhu et al., 2006; Fang et al., 2007; Wang et al., 2012) and implies that the lithofacies change was not a local event but rather a basinwide event due to an overall increase in aridity between $3.1 \mathrm{Ma}$ and 2.6 $\mathrm{Ma}$ in the region.

\section{Controls on Sedimentation in the Qaidam Basin}

One of the overarching focuses of this study is to differentiate the climatic versus tectonic effects on sedimentation within the Qaidam Basin. To this end, new detailed stratigraphic and sedimentologic analyses combined with magnetostratigraphic age control and structural observations provide evidence for the temporal relationships between distinct climatic and tectonic events. Despite the fact that this study focused on only one location within the basin, our data provide a new interpretation of the Qaidam Basin paleogeography over the last 5 m.y. (Fig. 12) and provide invaluable insight into the potential linkages among climate change, basin deformation, and sedimentation.

\section{Extrabasin Deformation as a Control on Qaidam Basin Deposition (5.2-3.1 Ma)}

Although sedimentation within the Qaidam Basin was continuous for much of the Cenozoic, our section begins near the core of a northwest-southeast-trending anticline at 5.2 Ma. From at least 5.2 Ma to 4.4 Ma, sedimentary facies were dominated by mud-flat and overbank mudstone and shale, with meandering fluvial channels that show paleoflow toward the northeast (Fig. 12A). The fluvial system through this part of the basin likely originated within fans to the south flanking the Kunlun Shan and fed a lacustrine depocenter northeast of our study locality in the northern Qaidam Basin adjacent to the Qilian Shan (fig. 13F in Yin et al., 2008). After 4.4 Ma, lacustrine sedimentation shifted to the southwest of the study section, and paleoflow reversed direction and entered the lacustrine setting from the northeast (Fig. 13B). This shift in depocenters is clearly observed in isopach maps of the Upper Youshashan (late Miocene) and Shizigou (Pliocene) Formations (fig. 4 in Zhu et al., 2006; figs. 13F and 13G in Yin et al., 2008), and in the paleocurrent directions observed in this study (Fig. 5). We speculate that subtle uplift on currently inactive roof duplex structures (fig. 13 in Yin et al., 2008) in the northern Qaidam Basin just south of the Qilian Shan around 4.4 Ma may have shifted the depocenter southward, causing a reversal in paleocurrent and a shift in provenance from the south to the north (Fig. 12B). Floodplain lithofacies M1 disappears from the strata at $4.5 \mathrm{Ma}$ and is coincident with the first appearance of gypsum, suggesting a subtle change to a closed, lacustrine depositional system during the depocenter reorganization after 4.4 Ma. Overall, lithofacies changes at ca. 4.4 Ma are not linked to changes in $\delta^{18} \mathrm{O}$ within global or local records, and the most likely cause of these changes is attributed to deformation and rock uplift along the northeastern margin of the Qaidam Basin. This tectonic deformation, however, did not lead to activation of the intrabasin folds in our study region (Fig. 2).

\section{Isotope Stratigraphy as Evidence for Climate Change at 3.1 Ma}

Authigenic carbonate in lacustrine and pedogenic environments provides a reliable means of understanding the $\delta^{18} \mathrm{O}$ of the meteoric water from which carbonate precipitated. The $\delta^{13} \mathrm{C}$ values track the dissolved inorganic carbon (DIC) composition of lake water (e.g., McKenzie, 1985) and the plant-respired $\mathrm{CO}_{2}$ composition of soils (Cerling et al., 1993). Between 5.2 and $3.1 \mathrm{Ma}$, both $\delta^{18} \mathrm{O}$ (average: $-6.8 \%$, range: $-4 \%$ o to $-10 \%$ ) and $\delta^{13} \mathrm{C}$ (average: $-4.6 \%$, range: $-8 \%$ to $-2 \%$ ) remain relatively consistent (Figs. 11 and 13). During this time, atmospheric $\mathrm{CO}_{2}$ concentrations were $30 \%$ higher than modern postindustrial values, and mean surface temperatures were $\sim 3{ }^{\circ} \mathrm{C}$ warmer (Van der Burgh, 1993; Raymo et al., 1996; Ravelo et al., 2004; Pagani et al., 2010). At 3.1 Ma, although $\delta^{13} \mathrm{C}$ values remain the same, $\delta^{18} \mathrm{O}$ values shift to more positive values (average: $-2.5 \%$ ) and become more variable (range: $-8 \%$ to $4 \%$ o). Our lacustrine carbonate $\delta^{18} \mathrm{O}$ values are consistent with marine records that shift toward more positive and variable values at approximately the same time, and with an increase in dust flux into the Pacific, implying drier and dustier conditions after 3.6 Ma (Fig. 13). This shift in lacustrine carbonate values is most simply explained by increased evaporation due to more arid conditions (e.g., Talbot, 1994). This interpretation is consistent with multiple proxy data sets suggesting that the late Pliocene "climate crash" had begun by ca. 3.0 Ma, resulting in a cooler and more arid climate in central Asia (e.g., Thunell and Belyea, 1982; Dwyer et al., 1995; Ravelo et al., 2004; H.-P. Zhang et al., 2012). Global climate change toward cooler, drier conditions may have produced the arid conditions observed (Zheng et al., 2010; H.-P. Zhang et al., 2012). 

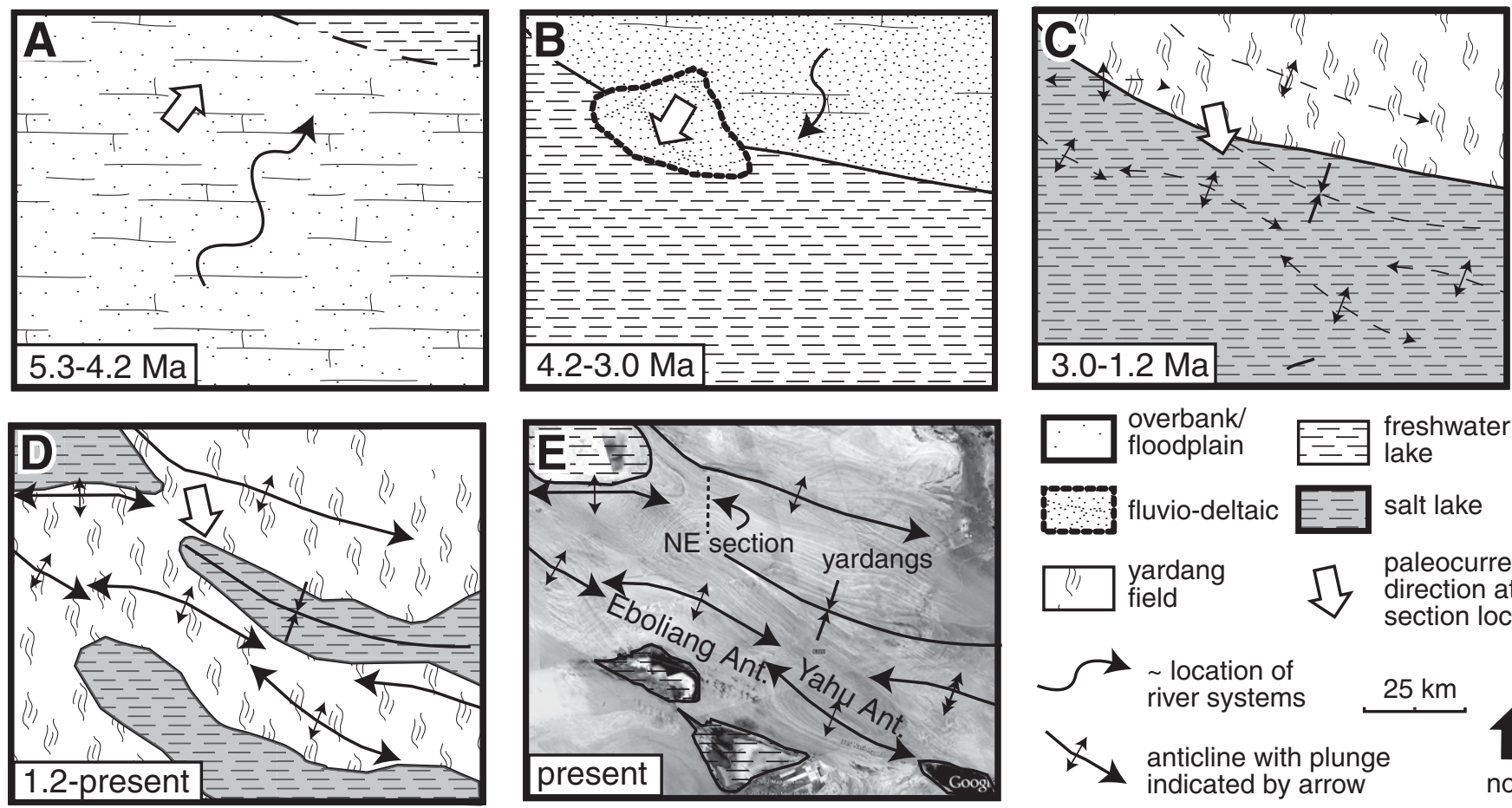

overbank/ floodplain

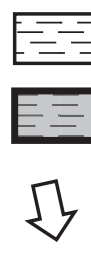

freshwater lake fluvio-deltaic yardang
field

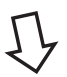
salt lake

paleocurrent direction at NE section location

$\sim$ location of river systems

$25 \mathrm{~km}$ anticline with plunge indicated by arrow

Figure 12. Paleogeographic map of the study area for each specific time interval and lithofacies association. (A) During the early Pliocene, low-gradient meandering river systems flowed northeast, likely toward a depocenter in the northern Qaidam Basin. (B) At 4.2 Ma, the drainage patterns reversed, lacustrine sediments were widespread in the central Qaidam Basin, and rivers flowed southwest from the Qilian Shan and deposited deltaic sediments in the freshwater lakes in the central Qaidam Basin. (C) By 3.0 Ma, aridification combined with uplift of the basin floor created saline depocenters and caused paleocurrents to shift subparallel to structures. Yardang formation initiated above some structures. (D) After 1.2 Ma, yardangs and paleosols periodically covered anticlinal crests and flanks during lake lowstands. (E) Presentday geography of the study area. Paleocurrents observed in the lacustrine sediments may reflect wind directions, and yardang fields are ubiquitous around the margins of the localized depocenters. Notice the extremely localized depocenters adjacent to the anticline crests.

The dramatic $\delta^{18} \mathrm{O}$ shift at $3.1 \mathrm{Ma}$, which was likely caused by a change to more arid conditions and increased evaporation near that time, is consistent with observed facies changes at the study location. At 3.0 Ma (1145 m), less than $100,000 \mathrm{yr}$ after the $\delta^{18} \mathrm{O}$ shift, lithofacies change from calcareous, well-cemented, continuous shale beds (M3) to mottled, discontinuous, shale and mudstone (M5). By 2.6 Ma (1235 m), the strata are dominated by evaporite-rich mudstone and shale. This lithofacies transition implies a change from shallow, possibly freshwater lacustrine deposition to evaporite conditions that occurred over $\sim 500,000 \mathrm{yr}$, and is consistent with global climate records that show climate cooling between 3.6 and 2.6 Ma (Fig. 13). Moreover, the time scale of lithofacies transition (3.1-2.6 Ma) overlaps with climate records on the Chinese Loess Plateau, where between 3.6 and $2.6 \mathrm{Ma}$ the Red Earth Formation was deposited under more humid conditions than today (Hao and Guo, 2004). Together, $\delta^{18} \mathrm{O}$ values combined with lithofacies changes suggest that climate was the primary control on lacustrine deposition after 3.1 Ma, although rain-shadow effects due to plateau uplift could have enhanced the climate signal (Poage and Chamberlain, 2001; Quade et al., 2011; Bershaw et al., 2012).

\section{Tectonic Partitioning of the Qaidam Basin after 3.0 Ma}

Growth strata appear in the section at 3.0 Ma, $\sim 80 \mathrm{~m}$ above the observed isotope shift and only $30 \mathrm{~m}$ after the climate-controlled lithofacies change to M5 deposition. As noted in the results section, however, these growth strata represent a minimum age, as older growth strata lower in the section may have been eroded during growth of the fold. Therefore, growth of the studied intrabasin fold may be synchronous with the observed facies changes or isotopic shifts. However, it is unlikely that initial fold growth would have affected the lacustrine depocenter, and this study yielded no evidence for a paleocurrent shift until after 2.6 Ma.

After 2.6 Ma (1245 m), fold development clearly affected the basin deposition. Paleocurrent indicators from deltaic fluvial deposition changed from southwest directed to southsoutheast, more parallel with fold orientation and consistent with valley-parallel paleocurrents. Topographic development of the anticline may have forced the paleocurrents to shift to a subparallel alignment along the lacustrine depocenters located in the evolving synclines (Fig. $12 \mathrm{C}$ ). The observed sedimentation rate decrease at $2.6 \mathrm{Ma}(1245 \mathrm{~m})$ likely resulted from loss of accommodation space above the fold flank. Paleoyardangs first appear at $2.4 \mathrm{Ma}(1265 \mathrm{~m})$ and imply that portions of the basin floor must have been differentially uplifted enough to be affected by wind processes. The high frequency of periodic gypsum matt deposition after $2.4 \mathrm{Ma}$ is most simply explained by small, closed-basin, lacustrine depocenters that have been partitioned and cut off from the remainder of the basin. Smaller basins facilitate total desiccation and precipitation of evaporate minerals. Overall, although $\delta^{18} \mathrm{O}$ and $\delta^{13} \mathrm{C}$ show a marked shift at 3.1 Ma, the paleocurrent directions seem to be more strongly influenced by structurally controlled depocenters from 2.6 to 1.2 Ma than by regional climate variability (e.g., precipitation patterns). Together, paleocurrents, evidence for localized surface uplift and erosion (e.g., 

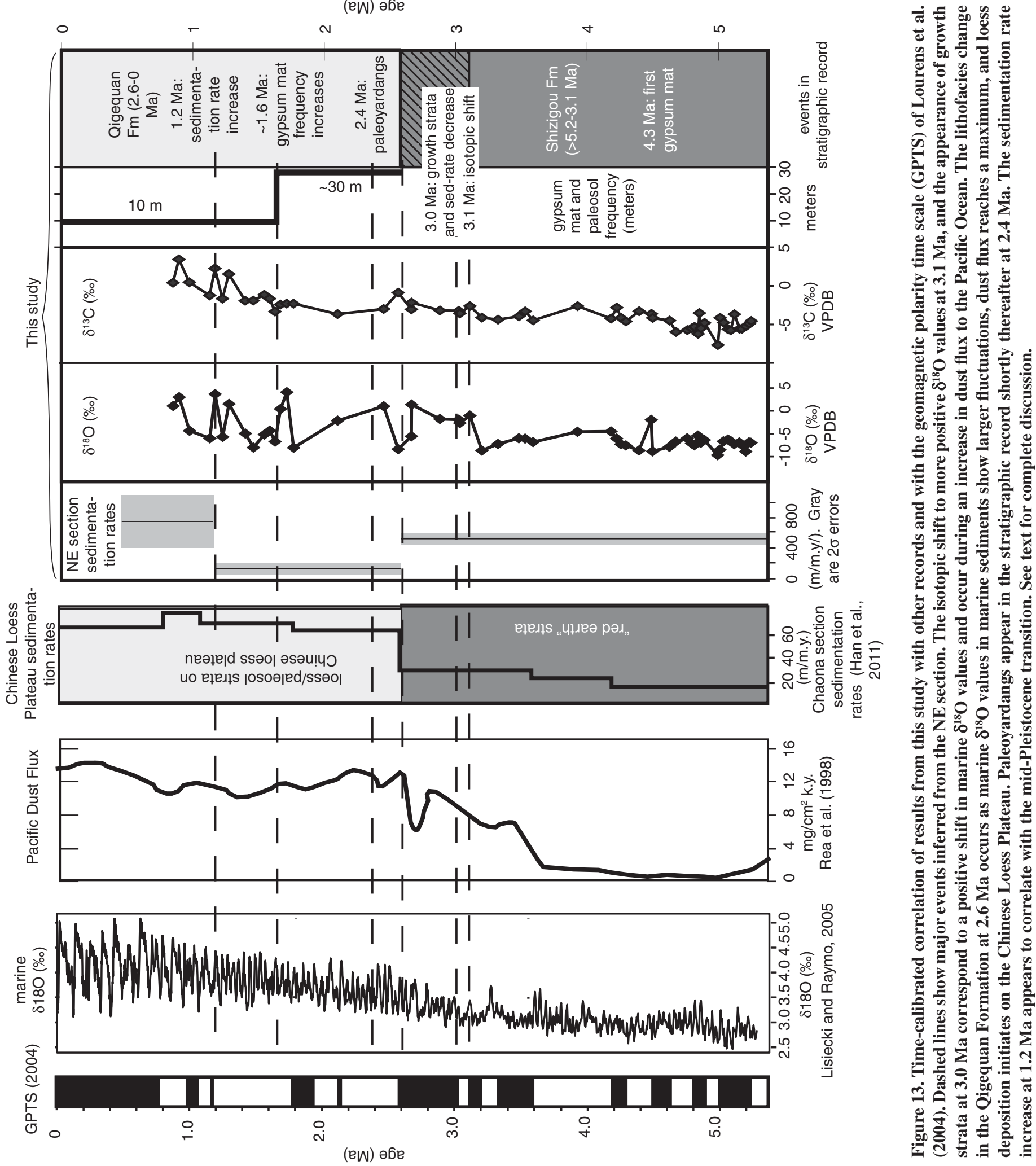
paleoyardangs), and increased evaporite frequency that postdate growth strata provide compelling evidence for a strong (but local) tectonic control on basin sedimentation.

\section{Post-2.6 Ma Climate Cycles}

Depositional facies changes that include wind deflation features, lacustrine wet-dry sequences, and abundant gypsum layers increase toward the present. We speculate that the high variability in the $\mathrm{O}$ - and $\mathrm{C}$-isotopes in the post-2.6 Ma Qigequan Formation is in phase with glacialinterglacial cyclicity, although our record was not sampled at the resolution needed to identify marine oxygen isotope stages correlating with Quaternary Northern Hemisphere glaciations. Based on our preliminary assessment, the frequency of gypsum beds and/or paleosols (lakelevel lowstands) may be controlled by oribitally controlled climate forcing.

Sedimentation rates within the Qigequan formation increase from $\sim 150 \mathrm{~m} / \mathrm{m}$.y. to $\sim 750 \mathrm{~m} / \mathrm{m}$.y. at $1.2 \mathrm{Ma}$, near the mid-Pleistocene transition. The mid-Pleistocene transition marks a change from obliquity-dominated $(40,000 \mathrm{yr})$ climate cycles to eccentricitydominated ( 100,000 yr) cycles (Fig. 13; Clark et al., 2006; Raymo et al., 2006). After 1.2 Ma, less frequent but more extreme climate fluctuations may have caused near-total desiccation of the Qaidam lakes, which would have promoted rapid evaporite sedimentation during the dry (and potentially windier) glacial periods. This hypothesis is supported by the increase in gypsum mats in the upper part of our section. Gypsum bed frequency increases at ca. 1.6 Ma from one bed every $34 \mathrm{~m}$ to one bed every $9.4 \mathrm{~m}$. After 1.6 Ma, a frequency of one gypsum bed every $9.4 \mathrm{~m}$ corresponds to a time interval between gypsum mats of only 13,000 yr (note the $40 \%$ error on rates) given a $730 \mathrm{~m} / \mathrm{m}$.y. sediment accumulation rate. Nevertheless, the gypsum mat frequency suggests that hyperarid conditions were persistent in the Qaidam Basin after 1.2 Ma. Although paleocurrents and depocenter locations seem to be controlled by the basin structures, the cyclicity observed within our strata is most likely controlled by orbital climate cycles that controlled lacustrine levels after this time.

The cause of the rapid increase in sedimentation rates observed after 1.2 Ma may be explained by localized depositional environments and an extremely windy climate. Dust flux would presumably be highest during the driest periods - those controlled by $100,000 \mathrm{yr}$ eccentricity-and thus rapid sedimentation would be promoted both within local basin depocenters as well as on the Chinese Loess Plateau. Loose lake sediments on the exposed basin floor would have been transported out of the basin, except where trapped in local depositional traps between the growing anticlines within the basin. Thus, entrapment of eolian sediments in localized depocenters combined with rapid evaporite precipitation in dry, mid-late Pleistocene conditions could have produced the high sedimentation rates observed after 1.2 Ma (Fig. 12D), but only in very localized depocenters within the Qaidam Basin (such as the top of the NE section within a syncline axis in this study; Fig. 2). Prior to $1.2 \mathrm{Ma}$, obliquity-dominated $(40,000 \mathrm{yr})$ climate cycles dominated the climate in the Qaidam Basin, and dust flux was lower into the Pacific (Rea et al., 1998); lake levels may have remained higher or had less time to desiccate, and hence there was less dust available to be deposited and transported.

The paleogeography for the region since 1.2 Ma has likely been relatively constant. Lacustrine depocenters have been confined to the synclinal depressions between anticlines, and strata are defined by lacustrine parasequences bounded by subaerial paleosols and salt crusts that formed during frequent desiccation of the lake bed. These locations are also the locations of playa and lacustrine depositional settings today (Figs. 12D-12E). Yardangs exposed at the surface presently are associated with the uplifted anticline crests and flanks. Active deposition occurs only in the depressions between the active structures, whereas wind deflation is greatest along the hinges of the regional-scale anticlines (Kapp et al., 2011).

\section{Paleoyardangs as a Proxy for Rock Uplift and Climate Change}

Yardangs are ubiquitous features in desert environments, but they have rarely been described within eolian and sabkha deposits within the stratigraphic record (Fryberger, 1986; Tewes and Loope, 1992; Jones and Blakey, 1993). The paucity of documented paleoyardangs in the global stratigraphic record is perplexing, but it may be explained by the three-dimensional analysis of the stratigraphy that is required to identify these stratigraphic features. Paleoyardangs must be interpreted in at least three dimensions, but the typical stratigraphic section is only one (borehole) or two (outcrop face) dimensional. Any one-dimensional section through a yardang would be interpreted simply as an angular unconformity or disconformity, depending on the section measured, but not as a paleoyardang. Furthermore, paleoyardangs may be carved into, and subsequently buried by, sedimentary rocks of very similar lithology (lacustrine in this case of the Qaidam Basin), which may complicate the observation of any unconformity either in outcrop or seismic data. Without excellent three-dimensional exposures, these features would be missed or simply explained as unconformities, cut-and-fill structures, or paleosols.

The identification and description of paleoyardangs are critical for interpreting paleoclimate, including paleo-wind directions and aridity, and rock uplift. For example, the paleoyardangs discussed here are aligned north-south, $\sim 45^{\circ}$ offset from the present yardang lineation and surface wind direction toward the southeast (Fig. 6). The reason for this apparent change is unknown, but it may be due to rotation of the paleoyardang along the active anticline flank or to differences in wind patterns during times of continental glaciations, when wind deflation was likely the greatest (Ganopolski et al., 1998; Clark et al., 1999). Nevertheless, paleoyardangs are associated with lake-level lowstands and paleosol formation, implying that lake levels may have been at minima (i.e., shallow localized saline lakes and salt marshes similar to today). In addition, deflation of the basin floor and formation of paleoyardangs require differential elevations of the basin floor, caused by uplift above active structures. The repeated occurrence of paleoyardangs within a stratigraphic section could thus be used to interpret changing climate cycles, regional wind patterns, and tectonic uplift, and they represent an under-utilized record of climate change and tectonics for comparison with other records such as the alternating loess/ paleosol stratigraphy of the Chinese Loess Plateau (Porter, 2001; Kapp et al., 2011).

\section{Implications for a Sediment Source for the Loess Plateau}

The stratigraphic record presented here contains compelling evidence for aridification at $3.1 \mathrm{Ma}$ based on shifts in the $\delta^{18} \mathrm{O}$ values of carbonate, basin partitioning beginning at 3.0 Ma based on growth strata, and basinwide change to the Qigequan Formation evaporites at 2.6 Ma. Most striking, however, is the appearance of paleoyardangs, and the associated wind erosion, in the stratigraphic record at 2.4 Ma. The Qigequan strata are associated with alternating paleosol/lacustrine sequences that suggest fluctuating lake levels after 2.6 Ma. Periodic subaerial exposure after 2.6 Ma, combined with continued uplift of the intrabasin structures, created an environment conducive to erosion of the friable, lacustrine strata. Because the Qaidam Basin is internally drained, is topographically isolated by surrounding mountain ranges, and is partitioned into local depocenters, the only viable mechanism for sediment removal from the basin is by wind (Fig. 1). Geological cross sections have shown that up to $3000 \mathrm{~m}$ of 
Pliocene-Quaternary lacustrine strata must have been removed from some areas of the Qaidam Basin since the start of the Quaternary (Kapp et al., 2011). Our observations of paleoyardangs in the Qaidam Basin imply a minimum onset age for large-scale wind erosion by $2.4 \mathrm{Ma}$, because paleoyardangs may be present elsewhere in the basin at lower (older) stratigraphic levels. Although eolian dust deposited on the Chinese Loess Plateau has been intermittent since $22 \mathrm{Ma}$, all documented Chinese Loess Plateau sections show a dramatic increase in sedimentation after 2.6 Ma (Fig. 13; Heller and Liu, 1982; Burbank and Li, 1985; Kukla, 1987; Ding et al., 1999; Sun et al., 1998; Guo et al., 2002; Hao and Guo, 2004). In fact, sedimentation rates on the Chinese Loess Plateau have continuously increased since ca. 2.6 Ma, including an $20 \%$ increase at ca. $1 \mathrm{Ma}$, consistent with our observations of increased aridity and differential uplift of the Qaidam Basin floor (Sun et al., 1998). The extensive desiccation of the Qaidam Basin floor, erosion of uplifted friable lacustrine strata, and coeval threefold increase in sedimentation rates on the Chinese Loess Plateau are an unlikely coincidence, and we suggest that the Qaidam Basin was a major source for the loess accumulated on the Chinese Loess Plateau during Quaternary time. This hypothesis is consistent with detrital zircon provenance data from the Chinese Loess Plateau and Qaidam Basin (Pullen et al., 2011; Xiao et al., 2012).

\section{CONCLUSIONS}

The Qaidam Basin provides some of the best and most areally extensive exposures of Pliocene-Quaternary lacustrine strata in the world. Our stratigraphic section spans 4.2 m.y. from 5.2 Ma to 0.8 Ma, and it contains evidence for lithologic and isotopic changes within the basin between $3.1 \mathrm{Ma}$ and $2.6 \mathrm{Ma}$, coincident with global climate cooling and ice-sheet development. At our study location between 5.2 Ma and $2.6 \mathrm{Ma}$, deposition was dominated by lake marginal and mud-flat environments with fluvial contribution (Shizigou Formation). A lithofacies change to more evaporite-rich strata closely followed a positive shift in $\delta^{18} \mathrm{O}$ values, consistent with the change to more arid conditions in the region at $3.1 \mathrm{Ma}$. This lithofacies transition is nearly synchronous with the initiation of deformation within the basin based on growth strata at 3.0 Ma. By 2.6 Ma, the strata are dominated by the evaporite lithofacies of the Qigequan Formation, and sedimentation rates decrease in the shallow, broad, localized lakes partitioned throughout the basin. After 1.2 Ma, a fivefold increase in sedimentation rates, a threefold increase in gypsum beds, and a shift to more posi- tive $\delta^{13} \mathrm{C}$ values are contemporaneous with the mid-Pleistocene transition and represent locally confined depocenters above active synclines and depositional environments dominated by hyperarid conditions. After $2.6 \mathrm{Ma}$, erosion of the recently exposed lacustrine strata above the active, intrabasin structures combined with lake-level fluctuation produced unique sedimentary structures (paleoyardangs) within the stratigraphic record. The presence of paleoyardangs at $2.4 \mathrm{Ma}$ implies that erosion of parts of the Qaidam Basin floor had initiated by that time, and may have provided the dominant source of eolian sediment for the Chinese Loess Plateau. Continued hyperarid conditions, especially after $1.2 \mathrm{Ma}$, promoted eolian erosion on the basin floor. Overall, our data suggest that climate change to more arid and fluctuating conditions after $3.1 \mathrm{Ma}$ controlled the depositional environment and lithofacies observed in the north-central Qaidam Basin, although deformation of the basin floor controlled the location of the depocenters.

\section{ACKNOWLEDGMENTS}

This research was supported by donors of the American Chemical Society Petroleum Research Fund (ACS PRF\#39376-G8), the U.S. National Science Foundation (grants EAR-0908778, EAR-1118525, AGS-1203427, AGS-1203973), and the China National Science Foundation (NSF-409211120406). B. Horton, B. Pratt, and an anonymous reviewer provided constructive, thoughtful reviews that improved this manuscript. We thank Pennilyn Higgins at the University of Rochester for assistance with the stable isotope analyses.

\section{REFERENCES CITED}

Bershaw, J., Penny, S.M., and Garzione, C.N., 2012, Stable isotopes of modern water across the Himalaya and eastern Tibetan Plateau: Implications for estimates of paleoelevation and paleoclimate: Journal of Geophysical Research, v. 117, no. D2, p. D02110, doi:10.1029/2011JD016132.

Besse, J., and Courtillot, V., 2002, Apparent and true polar wander and the geometry of the geomagnetic field over the last 200 Myr: Journal of Geophysical Research, v. 107 , no. B11, p. 2300.

Bridge, J.S., 2003, Rivers and Floodplains: Forms, Processes, and Sedimentary Record: London, Scientific Publications, $491 \mathrm{p}$.

Burbank, D.W., and Li, J., 1985, The age and palaeoclimatic implications of the loess of Lanzhou, north China: Nature, v. 316, p. 429-431, doi:10.1038/316429a0.

Butler, R.F., 1992, Paleomagnetism: London, Blackwell Scientific Publications, 319 p.

Cerling, T.E., Wang, Y., and Quade, J., 1993, Expansion of C4 ecosystems as an indicator of global ecological change in the late Miocene: Nature, v. 361, p. 344-345, doi:10.1038/361344a0.

Chang, M., Wang, X., Liu, H., Miao, D., Zhao, Q., Wu, G., Liu, J., Li, Q., Sun, Z., and Wang, N., 2008, Extraordinarily thick-boned fish linked to the aridification of the Qaidam Basin (northern Tibetan Plateau): Proceedings of the National Academy of Sciences of the United States of America, v. 105, no. 36, p. 13,246-13,251, doi:10.1073/pnas.0805982105.

Chen, J., Burbank, D.W., Scharer, K.M., Sobel, E., Yin, J., Rubin, C., and Zhao, R., 2002, Magnetostratigraphy of the Upper Cenozoic strata in the southwestern Chinese Tian Shan: Rates of Pleistocene folding and thrusting:
Earth and Planetary Science Letters, v. 195, p. 113 130, doi:10.1016/S0012-821X(01)00579-9.

Chen, K., and Bowler, J.M., 1986, Late Pleistocene evolution of salt lakes in the Qaidam Basin, Qinghai province, China: Palaeogeography, Palaeoclimatology, Palaeoecology, v. 54, no. 1-4, p. 87-104.

Chen, W.-P., Chen, C.-Y., and Naelek, J.L., 1999, Presentday deformation of the Qaidam basin with implications for intra-continental tectonics: Tectonophysics, v. 305 no. $1-3$, p. $165-181$

Clark, P.U., Alley, R.B., and Pollard, D., 1999, Northern Hemisphere ice-sheet influences on global climate change: Science, v. 286, no. 5442, p. 1104-1111, doi:10.1126/science.286.5442.1104.

Clark, P.U., Archer, D., Pollard, D., Blum, J.D., Rial, J.A., Brovkin, V., Mix, A.C., Pisias, N.G., and Roy, M., 2006, The middle Pleistocene transition: Characteristics, mechanisms, and implications for long-term changes in atmospheric $\mathrm{pCO}_{2}$ : Quaternary Science Reviews, v. 25 , no. 23 , p. $3150-3184$, doi: $10.1016 / \mathrm{j}$ .quascirev.2006.07.008.

Craddock, W., Kirby, E., and Zhang, H., 2011, Late Miocene-Pliocene range growth in the interior of the northeastern Tibetan Plateau: Lithosphere, v. 3, no. 6, p. 420-438, doi:10.1130/L159.1.

Ding, Z.L., Xiong, S.F., Sun, J.M., Yang, S.L., Gu, Z.Y., and Liu, T.S., 1999, Pedostratigraphy and paleomagnetism of a 7.0 Ma eolian loess-red clay sequence at Lingtai, Loess Plateau, north-central China and the implications for paleomonsoon evolution: Palaeogeography, Palaeoclimatology, Palaeoecology, v. 152, p. 49-66, doi:10.1016/S0031-0182(99)00034-6.

Doublet, S.F., and Garcia, J.-P., 2004, The significance of dropstones in a tropical lacustrine setting, eastern Cameros Basin (Late Jurassic-Early Cretaceous, Spain): Sedimentary Geology, v. 163, no. 3-4, p. 293309, doi:10.1016/j.sedgeo.2003.07.003.

Drummond, C.N., Patterson, W.P., and Walker, J.C.G., 1995 , Climatic forcing of carbon-oxygen isotopic covariance in temperate-region marl lakes: Geology, v. 23, no. 11,p. 10311034, doi:10.1130/0091-7613(1995)023<1031:CFOCOI $>2.3 . \mathrm{CO} ; 2$.

Dupont-Nivet, G., Guo, Z., Butler, R.F., and Jia, C., 2002, Discordant paleomagnetic direction in Miocene rocks from the central Tarim Basin: Evidence for local deformation and inclination shallowing: Earth and Planetary Science Letters, v. 199, no. 3, p. 473-482.

Dwyer, G.S., Cronin, T.M., Baker, P.A., Raymo, M.E., Buzas, J.S., and Corrège, T., 1995, North Atlantic Deepwater temperature change during late Pliocene and late Quaternary climate cycles: Science, v. 270, p. $1347-$ 1351, doi:10.1126/science.270.5240.1347.

Fang, X., Garzione, C., Van der Voo, R., Li, J., and Fan, M., 2003, Flexural subsidence by $29 \mathrm{Ma}$ on the NE edge of Tibet from the magnetostratigraphy of Linxia Basin, China: Earth and Planetary Science Letters, v. 210, no. 3-4, p. 545-560, doi:10.1016/ S0012-821X(03)00142-0.

Fang, X., Zhang, W., Meng, Q., Gao, J., Wang, X., King, J., Song, C., Dai, S., and Miao, Y., 2007, High-resolution magnetostratigraphy of the Neogene Huaitoutala section in the eastern Qaidam Basin on the NE Tibetan Plateau, Qinghai Province, China, and its implication on tectonic uplift of the NE Tibetan Plateau: Earth and Planetary Science Letters, v. 258, no. 1, p. 293-306, doi:10.1016/j.epsl.2007.03.042.

Fang, X., Wu, F., Han, W., Wang, Y., Zhang, X., and Zhang, W., 2008, Plio-Pleistocene drying process of Asian inland-Sporopollen and salinity records from Yahu section in the central Qaidam Basin: Quaternary Sciences, v. 28 , no. 5 , p. $875-882$.

Fryberger, S.G., 1986, Stratigraphic traps for petroleum in wind-laid rocks: The American Association of Petroleum Geologists Bulletin, v. 70, p. 1765-1776.

Ganopolski, A., Rahmstorf, S., Petoukhov, V., and Claussen, M., 1998, Simulation of modern and glacial climates with a coupled global model of intermediate complexity: Nature, v. 391 , no. 6665 , p. $351-356$, doi:10.1038/34839.

Garzione, C.N., Dettman, D.L., and Horton, B.K., 2004, Carbonate oxygen isotope paleoaltimetry: Evaluating the effect of diagenesis on estimates of paleoelevation 
in Tibetan Plateau basins: Palaeogeography, Palaeoclimatology, Palaeoecology, v. 212, p. 219-240.

Glennie, K.W., 1970, Desert Sedimentary Environments: Amsterdam, Elsevier, Developments in Sedimentology $14,211 \mathrm{p}$.

Goudie, A.S., 2007, Mega-yardangs: A global analysis: Geography Compass, v. 1, no. 1, p. 65-81, doi:10.1111/j.1749-8198.2006.00003.x.

Guo, Z.T., Peng, S.Z., Hao, Q.Z., Biscaye, P.E., and Liu, T.S., 2001, Origin of the Miocene-Pliocene Red-Earth Formation at Xifeng in northern China and implications for paleoenvironments: Palaeogeography, Palaeoclimatology, Palaeoecology, v. 170, no. 1-2, p. 11-26, doi:10.1016/S0031-0182(01)00235-8.

Guo, Z.T., Ruddiman, W.F., Hao, Q.Z., Wu, H.B., Qiao, Y.S., Zhu, R.X., Peng, S.Z., Wei, J.J., Yuan, B.Y., and Liu, T.S., 2002, Onset of Asian desertification by 22 Myr ago inferred from loess deposits in China: Nature, v. 416, no. 6877 , p. 159-163, doi:10.1038/416159a.

Halimov, M., and Fezer, F., 1989, Eight yardang types in Central Asia: Zeitschrift für Geomorphologie, v. 33, no. 4 , p. 205-217.

Han, W., Fang, X., Berger, A., and Yin, Q., 2011, An astronomically tuned 8.1 Ma eolian record from the Chinese Loess Plateau and its implication on the evolution of Asian monsoon: Journal of Geophysical Research, v. 116, no. D24, p. D24114, doi:10 .1029/2011JD016237.

Hao, Q., and Guo, Z., 2004, Magnetostratigraphy of a late Miocene-Pliocene loess-soil sequence in the western Loess Plateau in China: Geophysical Research Letters, v. 31, no. 9, p. L09209, doi:10.1029/2003GL019392.

Hardie, L.A., Smoot, J.P., and Eugster, H.P., 1978, Saline lakes and their deposits: A sedimentological approach, in Matter, A., ed., Lake Sediments: London, Blackwell Scientific Publications, p. 7-41.

Heller, F., and Liu, T.S., 1982, Magnetostratigraphical dating of loess deposits in China: Nature, v. 300, p. 431-433.

Horton, B.K., Dupont-Nivet, G., Zhou, J., Waanders, G.L., Butler, R.F., and Wang, J., 2004, Mesozoic-Cenozoic evolution of the Xining-Minhe and Dangchang Basins, northeastern Tibetan Plateau: Magnetostratigraphic and biostratigraphic results: Journal of Geophysical Research, v. 109, p. B04402, doi:10.1029/2003JB002913.

Hough, B.G., Garzione, C.N., Wang, Z., Lease, R.O., Burbank, D.W., and Yuan, D., 2011, Stable isotope evidence for topographic growth and basin segmentation Implication for the evolution of the NE Tibetan Plateau: Geological Society of America Bulletin, v. 123, p. 168-185, doi:10.1130/B30090.1.

Hsu, H.H., and Liu, X., 2003, Relationship between the Tibetan Plateau heating and East Asian summer monsoon rainfall: Geophysical Research Letters, v. 30, 4 p., doi 10.1029/2003GL017909.

Johnson, N.M., Opdyke, N.D., Johnson, G.D., Lindsay, E.H., and Tahirkheli, R.A.K., 1982, Magnetic polarity stratigraphy and ages of Siwalik Group rocks of the Potwar Plateau, Pakistan: Palaeogeography, Palaeoclimatology, Palaeoecology, v. 37, p. 17-42, doi:10.1016/0031-0182(82)90056-6.

Jones, C.H., 2002, User-driven integrated software lives: "PaleoMag": Paleomagnetics analysis on the Macintosh: Computers and Geosciences, v. 28 , no. 10 p. $1145-1151$

Jones, L.S., and Blakey, R.C., 1993, Erosional remnants and adjacent unconformities along an aeolian-marine boundary of the Page Sandstone and Carmel Formation, Middle Jurassic, south-central Utah: Journal of Sedimentary Research, v. 63, p. 852-859.

Kapp, P., Pelletier, J.D., Rohrmann, A., Heermance, R.V. Russell, J., and Lin, D., 2011, Wind erosion in the Qaidam Basin, central Asia: Implications for tectonics, paleoclimate, and the source of the Loess Plateau: GSA Today, v. 21 , no. $4 / 5$, p. $4-10$, doi:10.1130/ GSATG99A.1.

Katz, A., and Kolodny, Y., 1977, The geochemical evolution of the Pleistocene Lake Lisan-Dead Sea system: Geochimica et Cosmochimica Acta, v. 41, p. 1609-1611, 1613-1626, doi:10.1016/0016-7037(77)90172-7.

Kempf, O., Schlunegger, F., Strunck, P., and Matter, A. 1998, Palaeomagnetic evidence for late Miocene rotation of the Swiss Alps: Results from the north
Alpine foreland basin: Terra Nova, v. 10, p. 6-10, doi:10.1046/j.1365-3121.1998.00164.x.

Kirschvink, J.L., 1980, The least-squares line and plane and the analysis of paleomagnetic data: Geophysical Journal of the Royal Astronomical Society, v. 62, p. 699718, doi:10.1111/j.1365-246X.1980.tb02601.x.

Kukla, G., 1987, Loess stratigraphy in central China: Quaternary Science Reviews, v. 6, no. 3-4, p. 191-219.

Lease, R.O., Burbank, D.W., Hough, B., Wang, Z., and Yuan, D., 2012, Pulsed Miocene range growth in northeastern Tibet: Insights from Xunhua Basin magnetostratigraphy and provenance: Geological Society of America Bulletin, v. 124 , no. 5/6, p. 657-677, doi:10.1130/ B30524.1.

Li, G., Pettke, T., and Chen, J., 2011, Increasing Nd isotopic ratio of Asian dust indicates progressive uplift of the north Tibetan Plateau since the middle Miocene: Geology, v. 39, p. 199-202, doi:10.1130/G31734.1.

Lisiecki, L.E., and Raymo, M.E., 2005, A PliocenePleistocene stack of 57 globally distributed benthic $\delta^{18} \mathrm{O}$ records: Paleoceanography, v. 20, no. 1 , p. PA1003, doi:10.1029/2004PA001071

Liu, D., Fang, X., Song, C., Dai, S., Zhang, T., Zhang, W., Miao, Y., Liu, Y., and Wang, J., 2010, Stratigraphic and paleomagnetic evidence of mid-Pleistocene rapid deformation and uplift of the NE Tibetan Plateau: Tectonophysics, v. 486 , no. $1-4$, p. $108-119$, doi:10.1016/j .tecto.2010.01.014.

Liu, Z., Wang, Y., Chen, Y., Li, X., and Li, Q., 1998, Magnetostratigraphy and sedimentologically derived geochronology of the Quaternary lacustrine deposits of a $3000 \mathrm{~m}$ thick sequence in the central Qaidam Basin, western China: Palaeogeography, Palaeoclimatology, Palaeoecology, v. 140, no. 1-4, p. 459-473.

Lourens, L.J., Hilgen, F.J., Laskar, J., Shackleton, N.J., and Wilson, D., 2004, The Neogene Period, in Gradstein, F.M., Ogg, J.G., and Smith, A., eds., Geological Time Scale: Cambridge, UK, Cambridge University Press, p. $409-440$

Manabe, S., and Broccoli, A.J., 1990, Mountains and arid climates of middle latitudes: Science, v. 247 , p. 192 195, doi:10.1126/science.247.4939.192.

Manabe, S., and Holloway, J.L., Jr., 1975, The seasonal variation of the hydrologic cycle as simulated by a global model of the atmosphere: Journal of Geophysical Research, v. 80, p. 1617-1649, doi:10.1029/ JC080i012p01617.

McCarthy, P.J., Martini, I.P., and Leckie, D.A., 1997, Anatomy and evolution of a Lower Cretaceous alluvial plain: Sedimentology and palaeosols in the upper Blairmore Group, south-western Alberta, Canada: Sedimentology, v. 44, p. 197-220, doi:10.1111/j.1365-3091.1997 .tb01521.x.

McFadden, P.L., and McElhinny, M.W., 1990, Classification of the reversal test in paleomagnetism: Geophysical Journal International, v. 103, p. 725-729, doi:10.1111/ j.1365-246X.1990.tb05683.x.

McKenzie, J., 1985, Carbon isotopes and productivity in the lacustrine and marine environments, in Stumm, W., ed., Chemical Processes in Lakes: New York, John Wiley and Sons, p. 99-118.

Métivier, F., Guademer, Y., Tapponnier, P., and Klein, M., 1999, Mass accumulation rates in Asia during the Cenozoic: Geophysical Journal International, v. 137, p. 280-318, doi:10.1046/j.1365-246X.1999.00802.x.

Mischke, S., Sun, Z., Herzschuh, U., Qiao, Z., and Sun, N., 2010, An ostracod-inferred large Middle Pleistocene freshwater lake in the presently hyper-arid Qaidam Basin (NW China): Quaternary International, v. 218, p. $74-85$.

Molnar, P., 2005, Mio-Pliocene growth of the Tibetan Plateau and evolution of East Asian climate: Palaeontologia Electronica, v. 8, no. 1, article 2, 23 p.

Morrill, C., and Koch, P.L., 2002, Elevation or alteration? Evaluation of isotopic constraints on paleoaltitudes surrounding the Eocene Green River Basin: Geology, v. 30, p. 151-154, doi:10.1130/0091-7613(2002)030<0151: EOAEOI $>2.0 . \mathrm{CO} ; 2$.

Ojha, T., Butler, R.F., Quade, J., DeCelles, P.G., Richards, D., and Upreti, B.N., 2000, Magnetic polarity stratigraphy of the Neogene Siwalik Group at Khutia Khola, far western Nepal: Geological
Society of America Bulletin, v. 112, p. 424-434, doi:10.1130/0016-7606(2000)112<424:MPSOTN $>2.0 . \mathrm{CO} ; 2$

Pagani, M., Liu, Z., LaRiviere, J., and Ravelo, A.C., 2010, High Earth-system climate sensitivity determined from Pliocene carbon dioxide concentrations: Nature Geoscience, v. 3, no. 1, p. 27-30, doi:10.1038/ngeo724.

Pang, X.-Q., Li, Y.-X., and Jiang, Z.-X., 2004, Key geological controls on migration and accumulation for hydrocarbons derived from mature source rocks in Qaidam Basin: Journal of Petroleum Science Engineering, v. 41, no. 1-3, p. 79-95, doi:10.1016/ S0920-4105(03)00145-1.

Pares, J.M., Van der Voo, R., Downs, W.R., Yan, M., and Fang, X., 2003, Northeastward growth and uplift of the Tibetan Plateau: Magnetostratigraphic insights from the Guide Basin: Journal of Geophysical Research, v. 108 , no. B1, p. 2017, doi:10.1029/2001JB001349.

Phillips, F., Zreda, M.G., Ku, T.-L., Luo, S., Huang, Q.I., Elmore, D., Kubik, P.W., and Sharma, P., 1993, ${ }^{230} \mathrm{Th} /{ }^{234} \mathrm{U}$ and ${ }^{36} \mathrm{Cl}$ dating of evaporite deposits from the western Qaidam Basin, China: Implications for glacial-period dust export from Central Asia: Geological Society of America Bulletin, v. 105, no. 12, p. 1606-1616, doi:10.1130/0016-7606(1993)105<1606:TUACDO $>2.3 . \mathrm{CO} ; 2$.

Pillans, B., and Naish, T., 2004, Defining the Quaternary: Quaternary Science Reviews, v. 23, no. 23-24, p. 2271-2282, doi:10.1016/j.quascirev.2004.07.006.

Poage, M.A., and Chamberlain, C.P., 2001, Empirical relationships between elevation and the stable isotope composition of precipitation and surface waters: Considerations for studies of paleoelevation change: American Journal of Science, v. 301, no. 1, p. 1-15, doi:10.2475/ajs.301.1.1

Porter, S.C., 2001, Chinese loess record of monsoon climate during the last glacial-interglacial cycle: Earth-Science Reviews, v. 54, no. 1-3, p. 115-128, doi:10.1016/ S0012-8252(01)00043-5.

Pratt, B.R., 1994, Seismites in the Mesoproterozoic Altyn Formation (Belt Supergroup), Montana: A test for tectonic control of peritidal carbonate cyclicity: Geology, v. 22, no. 12, p. 1091-1094, doi:10.1130/0091-7613(1994)022<1091:SITMAF $>2.3 . \mathrm{CO} ; 2$

Pullen, A., Kapp, P., McCallister, A.T., Chang, H., Gehrels, G.E., Garzione, C.N., Heermance, R.V., and Ding, L. 2011, Qaidam Basin and northern Tibetan Plateau as dust sources for the Chinese Loess Plateau and paleoclimatic implications: Geology, v. 39, no. 11, p. 10311034, doi:10.1130/G32296.1.

Quade, J., Breecker, D.O., Daèron, M., and Eiler, J., 2011, The paleoaltimetry of Tibet: An isotopic perspective: American Journal of Science, v. 311, no. 2, p. 77-115, doi: 10.2475/02.2011.01

Ravelo, A.C., Andreasen, D.H., Lyle, M., Lyle, A.O., and Wara, M.W., 2004, Regional climate shifts caused by gradual global cooling in the Pliocene Epoch: Nature, v. 429, p. 263-267, doi:10.1038/nature02567.

Raymo, M.E., and Ruddiman, W.F., 1992, Tectonic forcing of late Cenozoic climate change: Nature, v. 359, p. 117-122, doi:10.1038/359117a0.

Raymo, M.E., Grant, B., Horowitz, M., and Rau, G.H., 1996, Mid-Pliocene warmth: Stronger greenhouse and stronger conveyor: Marine Micropaleontology, v. 27, p. 313-326, doi:10.1016/0377-8398(95)00048-8.

Raymo, M.E., Lisiecki, L.E., and Nisancioglu, K.H., 2006, Plio-Pleistocene ice volume, Antarctic climate, and the global $\delta^{18} \mathrm{O}$ record: Science, v. 313 , no. 5786 , p. $492-$ 495, doi:10.1126/science. 1123296

Rea, D.K., Snoeckx, H., and Joseph, L.H., 1998, Late Cenozoic eolian deposition in the North Pacific: Asian drying, Tibetan uplift, and cooling of the northern hemisphere: Paleoceanography, v. 13, no. 3, p. 215-224.

Riba, O., 1976, Syntectonic unconformities of the Alto Cardener, Spanish Pyrenees: A genetic interpretation: Sedimentary Geology, v. 15, p. 213-233, doi:10.1016/0037-0738(76)90017-8.

Rieser, A., Neubauer, F., Liu, Y., and Ge, X., 2005, Sandstone provenance of north-western sectors of the intracontinental Cenozoic Qaidam Basin, western China: 


\section{Heermance et al.}

Tectonic vs. climatic control: Sedimentary Geology, v. 177, p. 1-18, doi:10.1016/j.sedgeo.2005.01.012.

Rieser, A., Bojar, A.-V., Neubauer, F., Genser, J., Liu, Y., Ge, X.-H., and Friedl, G., 2009, Monitoring Cenozoic climate evolution of northeastern Tibet: Stable isotope constraints from the western Qaidam Basin, China: International Journal of Earth Sciences, v. 98, no. 5, p. 1063-1075, doi:10.1007/s00531-008-0304-5.

Rubin, D.M., and Hesp, P.A., 2009, Multiple origins of linear dunes on Earth and Titan: Nature Geoscience, v. 2, no. 9, p. 653-658, doi:10.1038/ngeo610.

Ruddiman, W.F., and Kutzbach, J.E., 1989, Forcing of the late Cenozoic Northern Hemisphere climate by plateau uplift in Southeast Asia and the American Southwest: Journal of Geophysical Research, v. 94, p. 18,409-418, 427, doi:10.1029/JD094iD15p18409.

Schlunegger, F., Jordon, T.E., and Klaper, E.M., 1997, Controls of erosional denudation in the orogen on foreland basin evolution: The Oligocene central Swiss molasse basin as an example: Tectonics, v. 16, p. 823-840, doi:10.1029/97TC01657.

Schreiber, B.C., and El Tabakh, M., 2000, Deposition and early alteration of evaporites: Sedimentology, v. 47, p. 215-238, doi:10.1046/j.1365-3091.2000.00002.x

Schubel, K.A., and Lowenstein, T.K., 1997, Criteria for the recognition of shallow-perennial-saline-lake halites based on recent sediments from the Qaidam Basin, western China: Journal of Sedimentary Research, v. 67 , no. 1 , p. $74-87$.

Smoot, J.P., and Castens-Seidell, B., 1994, Sedimentary features produced by efflorescent salt crusts, Saline Valley and Death Valley, California, in Last, W.M., ed., Sedimentology and Geochemistry of Modern and Ancient Saline Lakes: Society of Economic Paleontologists and Mineralogists Special Publication 50, p. 73-90.

Song, T., and Wang, X., 1993, Structural styles and stratigraphic patterns of syndepositional faults in a contractional setting; examples from Qaidam Basin, northwestern China: The American Association of Petroleum Geologists Bulletin, v. 77, no. 1, p. 102-117.

Stiller, M., Rounick, J.S., and Shasha, S., 1985, Extreme carbon-isotope enrichments in evaporating brines: Nature, v. 316, p. 434-435, doi:10.1038/316434a0.

Suarez, M.B., Passey, B.H., and Kaakinen, A., 2011, Paleosol carbonate multiple isotopologue signature of active East Asian summer monsoons during the late Miocene and Pliocene: Geology, v. 39, no. 12, p. 1151-1154, doi:10.1130/G32350.1.

Sun, D., An, Z., Shaw, J., Bloemendal, J., and Sun, Y., 1998, Magnetostratigraphy and palaeoclimatic significance of Late Tertiary aeolian sequences in the Chinese Loess Plateau: Geophysical Journal International, v. 134, no. 1, p. 207-212, doi:10.1046/j.1365-246x.1998.00553.x

Sun, J., and Liu, T., 2000, Stratigraphic evidence for the uplift of the Tibetan Plateau between 1.1 and $0.9 \mathrm{Myr}$ ago: Quaternary Research, v. 54, no. 3, p. 309-320, doi:10.1006/qres.2000.2170.

Suppe, J., Sàbat, F., Muñoz, J.A., Poblet, J., Roca, E., and Vergés, J., 1997, Bed-by-bed fold growth by kink-band migration: Sant Llorenç de Morunys, eastern Pyrenees: Journal of Structural Geology, v. 19, p. 443-461, doi:10.1016/S0191-8141(96)00103-4.

Talbot, M.R., 1994, Paleohydrology of the late Miocene Ridge basin lake, California: Geological Society of America Bulletin, v. 106, no. 9, p. 1121-1129,
doi:10.1130/0016-7606(1994)106<1121:POTLMR>2 .3.CO;2.

Talbot, M.R., and Kelts, K., 1990, Paleolimnological signatures from carbon and oxygen isotopic ratios in carbonates from organic carbon-rich lacustrine sediments, in Katz, B.J., ed., Lacustrine Basin Exploration-Case Studies and Modern Analogs: American Association of Petroleum Geologists Memoir 50, p. 99-112.

Tan, X., Kodama, K.P., Chen, H., Fang, D., Sun, D., and Li, Y., 2003, Paleomagnetism and magnetic anisotropy of Cretaceous red beds from the Tarim Basin, northwest China: Evidence for a rock magnetic cause of anomalously shallow paleomagnetic inclinations from central Asia: Journal of Geophysical Research, v. 108, no. B2, p. 2107, doi:10.1029/2001JB001608.

Tewes, T.W., and Loope, D.B., 1992, Palaeo-yardangs: Wind-scoured desert landforms at the Permo-Triassic unconformity: Sedimentology, v. 39, p. 251-261, doi:10.1111/j.1365-3091.1992.tb01037.x.

Thunell, R., and Belyea, P., 1982, Neogene planktonic foraminiferal biogeography of the Atlantic Ocean: Micropaleontology, v. 28, p. 381-398, doi:10.2307/1485451.

Van Der Burgh, J., Visscher, H., Dilcher, D.L., and Kürschner, W.M., 1993, Paleoatmospheric signatures in Neogene fossil leaves: Science, v. 260, p. 1788 1790, doi:10.1126/science.260.5115.1788.

Wang, Q., and Coward, M.P., 1990, The Chaidam Basin (NW China): Formation and hydrocarbon potential: Journal of Petroleum Geology, v. 13, no. 1, p. 93-112.

Wang, X., Qiu, Z., Li, Q., Wang, B., Qiu, Z., Downs, W.R., Xie, G., Xie, J., Deng, T., Takeuchi, G.T., Tseng, Z.J., Chang, M., Liu, J., Wang, Y., Biasatti, D., Sun, Z., Fang, X., and Meng, Q., 2007, Vertebrate paleontology, biostratigraphy, geochronology, and paleoenvironment of Qaidam Basin in northern Tibetan Plateau: Palaeogeography, Palaeoclimatology, Palaeoecology, v. 254 , no. $3-4$, p. $363-385$, doi: $10.1016 / \mathrm{j}$ palaeo.2007.06.007

Wang, Y., Zhen, J., Zhang, W., Li, S., Liu, X., Yang, X., and Liu, Y., 2012, Cenozoic uplift of the Tibetan Plateau: Evidence from the tectonic-sedimentary evolution of the western Qaidam Basin: Geoscience Frontiers, v. 3, no. 2, p. 175-187, doi:10.1016/j.gsf.2011.11.005.

Xia, W., Zhang, N., Yuan, X., Fan, L., and Zhang, B., 2001, Cenozoic Qaidam Basin, China: A stronger tectonic inversed, extensional rifted basin: The American Association of Petroleum Geologists Bulletin, v. 85, no. 4, p. $715-736$

Xiao, G., Zong, K., Li, G., Hu, Z., Dupont-Nivet, G., Peng, S., and Zhang, K., 2012, Spatial and glacial-interglacial variations in provenance of the Chinese Loess Plateau: Geophysical Research Letters, v. 39, p. L20715, doi:10.1029/2012GL053304.

Yin, A., Dang, Y.-Q., Zhang, M., Chen, X.-H., and McRivette, M.W., 2008, Cenozoic tectonic evolution of the Qaidam Basin and its surrounding regions (Part 3): Structural geology, sedimentation, and regional tectonic reconstruction: Geological Society of America Bulletin, v. 120, no. 7-8, p. 847-876, doi:10.1130/B26232.1.

Zaleha, M., 1997, Fluvial and lacustrine paleoenvironments of the Miocene Siwalik Group, Khaur area, Pakistan: Sedimentology, v. 44, p. 349-368, doi:10.1111/j.1365-3091.1997.tb01529.x.

Zhang, H.-P., Craddock, W.H., Lease, R.O., Wang, W.-t., Yuan, D.-Y., Zhang, P.-Z., Molnar, P., Zheng, D.-W., and Zheng, W.-J., 2012, Magnetostratigraphy of the Neogene Chaka Basin and its implications for mountain building processes in the north-eastern $\mathrm{Ti}$ betan Plateau: Basin Research, v. 24, no. 1, p. 31-50, doi:10.1111/j.1365-2117.2011.00512.x.

Zhang, P., Molnar, P., and Downs, W.R., 2001, Increased sedimentation rates and grain sizes $2-4 \mathrm{Myr}$ ago due to the influence of climate change on erosion rates: $\mathrm{Na}$ ture, v. 410, p. 891-897, doi:10.1038/35073504

Zhang, W., Appel, E., Fang, X., Song, C., and Cirpka, O., 2012a, Magnetostratigraphy of deep drilling core SG-1 in the western Qaidam Basin (NE Tibetan Plateau) and its tectonic implications: Quaternary Research, v. 78, no. 1, p. 139-148, doi:10.1016/j.yqres.2012.03.011.

Zhang, W., Appel, E., Fang, X., Yan, M., Song, C., and Cao, L., 2012b, Paleoclimatic implications of magnetic susceptibility in late Pliocene-Quaternary sediments from deep drilling core SG-1 in the western Qaidam Basin (NE Tibetan Plateau): Journal of Geophysical Research, v. 117, no. B6, p. B06101, doi:10.1029/2011JB008949.

Zheng, D.W., Clark, M.K., Zhang, P.Z., Zheng, W., and Farley, K.A., 2010, Erosion, fault initiation and topographic growth of the North Qilian Shan (northern Tibetan Plateau): Geosphere, v. 6, no. 6, p. 937-941, doi:10.1130/GES00523.1

Zheng, H., Powell, C.M., An, Z., Zhou, J., and Dong, G., 2000, Pliocene uplift of the northern Tibetan Plateau: Geology, v. 28, p. 715-718, doi:10.1130/0091-7613(2000)28<715:PUOTNT $>2.0 . \mathrm{CO} ; 2$.

Zhou, J., Xu, F., Wang, T., Cao, A., and Yin, C., 2006, Cenozoic deformation history of the Qaidam Basin, NW China: Results from cross-section restoration and implications for Qinghai-Tibet Plateau tectonics: Earth and Planetary Science Letters, v. 243, no. 1-2, p. 195 210, doi:10.1016/j.epsl.2005.11.033.

Zhu, L., Wang, C., Zheng, H., Xiang, F., Yi, H., and Liu, D. 2006, Tectonic and sedimentary evolution of basins in the northeast of Qinghai-Tibet Plateau and their implication for the northward growth of the plateau: Palaeogeography, Palaeoclimatology, Palaeoecology, v. 241, p. 49-60, doi:10.1016/j.palaeo.2006.06.019.

Zhuang, G., Hourigan, J.K., Koch, P.L., Ritts, B.D., and Kent-Corson, M.L., 2011a, Isotopic constraints on intensified aridity in Central Asia around $12 \mathrm{Ma}$ : Earth and Planetary Science Letters, v. 312, no. 1-2, p. 152 163, doi:10.1016/j.epsl.2011.10.005.

Zhuang, G., Hourigan, J.K., Ritts, B.D., and Kent-Corson, M.L., 2011b, Cenozoic multiple-phase tectonic evolution of the northern Tibetan Plateau: Constraints from sedimentary records from Qaidam Basin, Hexi Corridor, and Subei Basin, northwest China: American Journal of Science, v. 311, no. 2, p. 116-152, doi:10.2475/02.2011.02.

ScIENCE Editor: A. Hope JAHREN

Associate Editor: Brian R. Pratt

Manuscript Received 19 June 2012

Revised Manuscript Received 6 November 2012

MANusCript ACCEPTEd 21 November 2012

Printed in the USA 


\title{
Geological Society of America Bulletin
}

\section{Climatic and tectonic controls on sedimentation and erosion during the Pliocene-Quarternary in the Qaidam Basin (China)}

\author{
Richard V. Heermance, Alex Pullen, Paul Kapp, Carmala N. Garzione, Scott Bogue, Lin Ding and \\ Peiping Song
}

Geological Society of America Bulletin published online 22 February 2013; doi: 10.1130/B30748.1

\section{Email alerting services}

Subscribe

Permission request click www.gsapubs.org/cgi/alerts to receive free e-mail alerts when new articles cite this article

click www.gsapubs.org/subscriptions/ to subscribe to Geological Society of America Bulletin

click http://www.geosociety.org/pubs/copyrt.htm\#gsa to contact GSA

Copyright not claimed on content prepared wholly by U.S. government employees within scope of their employment. Individual scientists are hereby granted permission, without fees or further requests to GSA, to use a single figure, a single table, and/or a brief paragraph of text in subsequent works and to make unlimited copies of items in GSA's journals for noncommercial use in classrooms to further education and science. This file may not be posted to any Web site, but authors may post the abstracts only of their articles on their own or their organization's Web site providing the posting includes a reference to the article's full citation. GSA provides this and other forums for the presentation of diverse opinions and positions by scientists worldwide, regardless of their race, citizenship, gender, religion, or political viewpoint. Opinions presented in this publication do not reflect official positions of the Society.

\section{Notes}

Advance online articles have been peer reviewed and accepted for publication but have not yet appeared in the paper journal (edited, typeset versions may be posted when available prior to final publication). Advance online articles are citable and establish publication priority; they are indexed by GeoRef from initial publication. Citations to Advance online articles must include the digital object identifier (DOIs) and date of initial publication.

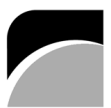

THE GEOLOGICAL SOCIETY OF AMERICA 